\title{
HRVATSKO-TALIJANSKI ODNOSI U ZADRU U VRIJEME RASPADA AUSTRO-UGARSKE MONARHIJE I TALIJANSKE OKUPACIJE (1918. - 1920.)
}

\author{
Ante GVERIĆ \\ Državni arhiv u Zadru \\ Zadar, Hrvatska
}

\author{
UDK: $94(497.5$ Zadar)“1918/1920“ \\ DOI: http://doi.org/10.21857/y54jofp8gm \\ Izvorni znanstveni članak \\ Prihvaćeno: 8. ožujka 2017.
}

U radu se analiziraju odnosi zadarskih Hrvata i Talijana u razdoblju razvijenih ideja nacionalnih integracija, za vrijeme kapitulacije Austro-Ugarske Monarhije i dolaska prvih talijanskih ratnih brodova i naposljetku tijekom dvogodišnje okupacije za trajanja poslijeratnih mirovnih pregovora. $\mathrm{Na}$ temelju izvornih arhivskih dokumenata, onodobnog tiska i odabrane literature zaključuje se da su međunacionalni odnosi u Zadru, uvjetovani političkim utjecajima, često prolazili teške faze netrpeljivosti i međusobnih sukoba.

Ključne riječi: Hrvati, Talijani, sukobi, Zadar, Austro-Ugarska Monarhija, 1918., talijanska okupacija.

\section{UVODNE NAPOMENE}

U Zadru se s vremena na vrijeme, u određenim prigodama, postavlja pitanje urbanog, odnosno zadarskog identiteta. Često se pritom može čuti da Zadar zapravo i nema jedinstveni i prepoznatljivi identitet poput drugih, ponajprije dalmatinskih gradova. Takve tvrdnje temelje se na činjenici da je grad, uslijed katastrofalnih posljedica bombardiranja u Drugom svjetskom ratu, kao i zbog neprijateljske politike komunističkog režima prema talijanskom stanovništvu, napustilo gotovo svo stanovništvo koje je osjećalo talijansku nacionalnu pripadnost. Tomu u prilog ide i činjenica da je u gotovo napušteni i razoreni grad u kratko vrijeme pristigao val doseljenika različitog nacionalnog, vjerskog i uopće kulturološkog porijekla. Usporede li se te poslijeratne prilike u Zadru sa stanjem u vrijeme razvijenih nacionalnih integracija s početka 20. stoljeća, uočit će se nepremostiva razlika: od grada koji je bio administrativno sjedište Dalmacije i žarište nacionalnih ideja i politika nije ostalo ništa. Nestao je grad koji je imao sva obilježja pokrajinskog središta - sva civilna, vojna i crkvena upravna tijela, golemo činovništvo, vojsku, javne društvene djelatnike različitih profila - grad

\footnotetext{
Ovaj je rad sufinancirala Hrvatska zaklada za znanost projektom br. 7822.
} 
u kojem su se tijekom zadnjih desetljeća austrijske uprave žestoko sukobljavale hrvatske i talijanske političke i kulturne snage, polažući pritom svoje pravo na grad te šireći svoj utjecaj na čitavu Dalmaciju.

Ovaj rad ${ }^{1}$ ima za cilj proniknuti u narav odnosa zadarskih Hrvata i Talijana u vrijeme završetka dugog 19. stoljeća, stoljeća nacija, i stvaranja novih društvenopolitičkih uređenja nakon Prvog svjetskog rata. U fokusu su dakle nacionalni odnosi koji su u Zadru, u tim prijelomnim vremenima nakon kojih je ovaj prostor doživio drastičnu društveno-političku transformaciju, formirali upravo ono što možemo nazvati zadarski identitet. (Predmet interesa u ovom radu nije odnos vlastî prema pojedinim nacionalnim skupinama, što zahtijeva posebnu raspravu.) U prvom poglavlju analiziraju se odnosi Hrvata i Talijana u okruženju AustroUgarske Monarhije u kojem su formirani aneksionistički i autonomistički idejni i politički pravci. Drugo poglavlje prikazuje međunacionalne odnose tijekom raspada Monarhije i neposrednog poraća kada je Italija temeljem Ugovora o primirju s Austro-Ugarskom kao sila saveznica okupirala bivše austrijske istočnojadranske krajeve. Posljednja cjelina analizira te odnose za vrijeme dvogodišnjih mirovnih pregovora i uređenja granica između Italije i Kraljevine SHS dok je Zadrom (i okupiranim dijelovima Dalmacije) upravljao guverner Enrico Millo, a na općinskoj razini načelnik Luigi Ziliotto.

Prikazom i analizom odnosa zadarskih Hrvata i Talijana, temeljenih na izvornom arhivskom gradivu, nastoji se doprinijeti rekonstrukciji identiteta Zadra u razdoblju od formiranja nacionalnih ideja do uspostave talijanskog suvereniteta nad Zadrom temeljem Rapallskog ugovora.

\section{ZADAR KAO UPRAVNO SREDIŠTE DALMACIJE I ŽARIŠTE AUTONOMISTIČKIH I ANEKSIONISTIČKIH SUKOBA}

Tijekom druge austrijske uprave Dalmacijom (1813. - 1918.) Zadar je za dalmatinske prilike postao moderno europsko pokrajinsko središte, ali je na koncu austrijske uprave i prestala njegova svekolika dominacija u Dalmaciji. Pod stoljetnom austrijskom administracijom Zadar je iz srednjovjekovnog utvrđenog grada preoblikovan u suvremeno administrativno središte Beču daleke i gotovo nepoznate, siromašne pokrajine Dalmacije. ${ }^{2}$ Zadar je tada dobio

1 Rezultati ovih istraživanja prikazani su na Petom kongresu hrvatskih povjesničara „Krize, sukobi i solidarnost u povijesnoj perspektivi“ koji se održavao u Zadru od 6. do 9. listopada 2016.

2 O izgradnji u Zadru za vrijeme austrijske uprave vidi više: Marija STAGLIčić, Graditeljstvo Zadra: od klasicizma do secesije, Zagreb, 2013. 
obilježje činovničkog grada u koji su službenici, uz one malobrojne domicilne, stizali iz raznih krajeva Austro-Ugarske Monarhije. Propašću Austro-Ugarske Monarhije u jesen 1918. Zadar je prestao biti upravno, ali i u svakom drugom smislu dalmatinsko središte.

Na početku druge upraveu Dalmaciji Austrijajeteritorijalno, administrativno i politički organizirala vlast tako da su u Zadru bila koncentrirana sjedišta svih pokrajinskih tijela javnih vlasti. ${ }^{4}$ Najviše upravno tijelo Kraljevine Dalmacije bila je Zemaljska vlada s guvernerom na čelu kao predstavnikom vojne i civilne vlasti, izravno podređena vladi u Beču. Novom administrativno-političkom organizacijom Dalmacije u neoapsolutističkom duhu, početkom pedesetih godina reorganizirana je pokrajinska vlast $s$ Namjesništvom, odnosno namjesnikom kao najvišim predstavnikom vlasti. ${ }^{5}$ Nakon Bachova apsolutizma u Zadru se 1861. konstituira pokrajinski Dalmatinski sabor i Zemaljski odbor kao njegovo izvršno tijelo. ${ }^{6}$ Djelovanjem Sabora kao predstavničkog tijela Zadar dodatno poprima komponentu okupljajućeg i upravnog središta u kojem su

3 Izvrstan opis Zadra dao je Zadranin i suvremenik ovih događaja Vladan Desnica: „Zadar je razvio jedan svoj specifični život i poprimio jedno naročito lice. Izgradio je svoju skroz naskroz gradsku i građansku fizionomiju, daleko više nego ma koji od ostalih dalmatinskih gradova. Razvio je jedan svoj zatvoreni, hermetički gradski život koji od sebe nije davao napolje ništa, a k sebi je od okolice primao, kroz naročite filtre i s naročitim predostrožnostima, sve što mu je moglo da posluži i da ga dalje u životu podrži. Živio je po svojim strogo utvrđenim i dugom tradicijom izbrušenim društvenim pravilima i konvencijama, sa svojim stopostotno građanskim mentalitetom i svojim uskim pogledom na svijet. Sav život njegovih građana tekao je po unaprijed utvrđenom redu, neodstupno, kao po nategnutoj žici, i svako kolebanje na toj žici značilo je za taj mentalitet opasnost pada u prazno, provaliju. Pozornica njihova života je popločani prostor, gradski trg, agora; kulise - stara arhitektura; vizuale - uske uličice slične kamenim žljebovima kroz koje teče život kanalizirano, krotko kao ulje iz starinskih tijeskova, između tri stranice od tesanog i uglačanom kamena. I u tim uličicama i toj arhitekturi tako je usko sljubljena ploča uz ploču i kamen uz kamen, da između njih ne može da se probije na božji dan ni najtananija travčica, kao blijeda i beskrvna afirmacija slobodne prirode i slobodnog života. Na tom „steriliziranom prostoru“, dakle, odigravao se život zadarskog građanina od rođenja do smrti. Po toj urbanosti, Zadar ne samo da je predstavljao nesumnjivo najgradskiji i najgrađanskiji ambijenat kod nas, nego je pripadao valjda među najgrađanskije ambijente evropskog Zapada." Vladan DesnicA, O jednom gradu i jednoj knjizi, Zadarska revija, III, br. 1, Zadar, 1954., 22, 23.

4 O formiranju i organizaciji uprave u Dalmaciji tijekom druge austrijske uprave više vidi: Stjepan AntolJak, Kako je nastala pokrajina Kraljevina Dalmacija, Časopis za hrvatsku povijest, 3/1943., 232 - 239; Frane Iv коvıć, Organizacija uprave u Dalmaciji za vrijeme druge austrijske vladavine 1814-1918., Arhivski vjesnik, 34-35/1991.-1992., 31 - 51; Stjepan Ćosıć, Obilježja i ustroj austrijske vlasti u Dalmaciji u doba apsolutizma, Radovi Zavoda za povijesne znanosti HAZU u Zadru, 40/1998., $349-360$.

5 O Vladi/Namjesništvu za Dalmaciju više vidi: Vodič Državnog arhiva u Zadru I, (gl. ur. Josip Kolanović), Zadar, 2014., 293 - 300; Dubravka Kolıć, Carsko-kraljevsko namjesništvo u Zadru 1814.-1918. Institucija i gradivo, Zadar, 2010.

6 Ivo Perić, Dalmatinski sabor 1861.-1912. (1918.), Zadar, 1978. 
djelovali političari iz cijele Dalmacije što je omogućilo nove i drugačije oblike političkog i uopće javno-društvenog djelovanja. Uz Namjesništvo, Sabor i Zemaljski odbor, u Zadru se nalaze središnja tijela pravosudne uprave, vojske i školstva, kao i crkvena, metropolitanska uprava. Zadar devetnaestog stoljeća postaje i kulturni centar Dalmacije u kojem djeluje niz kulturnih ustanova i društava, uredništava i tiskara različitih novina - Zadar je, na koncu, dom mnogim istaknutim pojedincima iz javnog života.

Sredina devetnaestog stoljeća, u Europi i na području hrvatskih zemalja, obilježena nacionalnim buđenjima, imala je odjeka i u Zadru, gdje se u procesima nacionalnih integracija formiraju dva osnovna pravca: slavodalmatinski, koji se do kraja Monarhije, preko autonomističkog, preoblikovao u talijansko-iredentistički pravac; te drugi pravac - aneksionistički, politički koncept hrvatske nacionalne integracije koji je pretendirao ujedinjenju/aneksiji Dalmacije s Hrvatskom i Slavonijom. ${ }^{7}$ Temelji ovih oprečnih političkih modela nalaze se prije svega u nacionalno podijeljenom stanovništvu Dalmacije čiji su narodni prvaci iznjedrili navedene političke pravce. Oba koncepta nastala su, i svaki na svoj način evoluirao, tijekom austrijske uprave u Dalmaciji, a talijanskoiredentistički je spletom međunarodno-političkih i diplomatskih događaja i preživio crno-žutu monarhiju te se i dijelom ozbiljio nakon Prvog svjetskog rata, odnosno poslijeratnih mirovnih konferencija. Međutim, takav razvoj događaja nije nalazio uporište u narodnosnom principu koji bi u demokratskim sustavima bio jedini određujući. Da je autonomistički koncept uopće zaživio i razvio se unatoč činjenici da je uz njega tijekom procesa nacionalnih integracija pristajao tek malen i neznatan dio dalmatinskog stanovništva - može se zahvaliti činjenici da je upravo taj dio stanovništva gotovo u potpunosti pripadao građanskom sloju dalmatinskog društva. Dalmatinski Talijani - kako su se u zrelom stadiju nacionalne integracije definirali pripadnici autonomističke, odnosno kasnije talijansko-iredentističke struje - potomci su prvenstveno Venecijanaca i Talijana iz ostalih talijanskih krajeva koji su tijekom četiristoljetne mletačke uprave Dalmacijom stizali u Zadar i Dalmaciju te ovdje ostajali kao činovnici mletačke uprave; ili su bili pripadnici plemstva koji su nakon ratova s Osmanlijama

7 O procesima nacionalnih integracija u Dalmaciji više vidi: Ante Bralić, Ante GverIć, Dalmazia irredenta - mitološki pogled na povijest, u: Dalmacija u prostoru i vremenu. Što Dalmacija jest, a što nije?, Zbornik radova, ur. Lena MirošEvić i Vera Graovas Matassi, Zadar, 2014., 111 124; Josip VRandečić, Dalmatinski autonomistički pokret u XIX. stoljeću, Zagreb, 2002.; Marko Trogrlić, Josip VRandečić (priredili), Dalmacija 1870-ih u svjetlu bečke politike i "istočnoga pitanja", Zadar, 2007.; Luciano Monzali, Italiani di Dalmazia. Dal Risorgimento alla Grande Guerra, vol 1, Firenze, 2004. 
dobivali posjede diljem Dalmacije, zatim razni trgovci, obrtnici, vojnici i drugi. Uz njihove potomke, koji su gotovo isključivo živjeli u urbanim sredinama i imali politički, gospodarski i uopće velik društveni utjecaj, u Dalmaciju se nakon mletačke uprave naseljavaju ponajviše Talijani iz sjevernotalijanskih krajeva kao državni službenici tijekom prve austrijske uprave u Dalmaciji (1797. - 1805.), francuske uprave (1806. - 1813.) i osobito od početka druge austrijske uprave iz onih krajeva koji su se do 1866. nalazili pod Austrijom. Valja, međutim, istaknuti i činjenicu da pristajanje uz autonomistički ili aneksionistički politički koncept nije bilo uvjetovano isključivo etničkom pripadnošću. Mnoštvo je primjera koji to dokazuju, bilo na jednoj ili na drugoj strani.

Uzroci nesrazmjera između društveno-političkog utjecaja autonomističkih, odnosno kasnije talijansko-iredentističkih skupina, i stvarnog broja talijanski govorećih stanovnika nalaze se ponajviše u baštini dugotrajnog, dominantnog $i$ izravnog mletačkog utjecaja koji je od početka 15. do konca 18. stoljeća prožeo sve pore dalmatinskog društva i tako ostavio neizbrisivih tragova u javnoj upravi, vjerskom životu, kulturi, školstvu, trgovini, ali i u mentalitetu svih Dalmatinaca, ne samo talijanskih društvenih slojeva. Istodobno, hrvatski slojevi nisu bili u poziciji razvijati općedruštveni utjecaj što je bilo uzrokom da je Dalmacija dočekala 19. stoljeće - stoljeće postanka modernih nacija - s pretežitim talijanskim utjecajem u svih društvenim sferama.

Austrijski popisi stanovništva devetnaestog $\mathrm{i}$ dva popisa provedena $\mathrm{u}$ dvadesetom stoljeću, iz kojih se narodnost iščitava iz jezika općenja (lingua d'uso), jasno ukazuju da je talijanski element u Dalmaciji činio znatnu manjinu stanovništva, što potkrepljuje navedenu tezu o nesrazmjeru broja Talijana u odnosu na njihov politički i kulturni utjecaj u dalmatinskom društvu. Takav odnos međutim nije bio u gradu Zadru gdje su talijanski govoreći stanovnici, odnosno oni koji su se deklarirali kao Talijani, činili većinu: od preko polovice do dvije trećine ukupnog stanovništva (ovisno o pojedinom popisu). U tumačenju rezultata popisa stanovništva obje su nacionalne skupine nastojale dokazivati netočnost statističkih podataka tamo gdje su bile u manjini, pripisujući ih makinacijama državnih vlasti koja je vršila popise: Talijani su branili talijanstvo Dalmacije, a Hrvati hrvatstvo Zadra. ${ }^{8}$

Nacionalnu pripadnost prema službenim popisima može se pratiti od popisa stanovništva 1880. godine kada je uvedena rubrika o jeziku općenja. ${ }^{9}$ Tada je u

8 Giotto Dainelli, La Dalmazia. Cenni geografici e statistici, Novara, 1918., 47; Je li „Zadar čisto talijanski grad“?, Hrvatska Kruna, br. 44, 23. studenog 1918.

9 Austrijski popisi stanovništva ovu su formu zadržali do zadnjeg popisa 1910. godine bez posebnog navođenja nacionalne pripadnosti. 
Dalmaciji živjelo 440279 onih koji su govorili hrvatskim jezikom, a 27305 onih koji su govorili talijanskim jezikom. ${ }^{10} \mathrm{U}$ Zadru je pak tada taj omjer bio 6676 naprama 5185, u korist talijanskih govornika. ${ }^{11}$ Dvadeset godina kasnije, pri popisu 1900. godine, u Dalmaciji je obitavalo gotovo četvrtina stanovnika više, dok je istovremeno broj Talijana skoro prepolovljen. ${ }^{12}$ Razlog drastičnog pada broja deklariranih Talijana u Dalmaciji bez sumnje je uvjetovan promjenom političkih snaga u dalmatinskim općinskim upravama gdje su u tom razdoblju vlast preuzele hrvatske političke opcije. Isti je, mada suprotan razlog povećanja broja Talijana u Zadru gdje je na vlasti ostala talijanska autonomistička stranka. ${ }^{13}$ Posljednji austrijski popis godine 1910. bilježi 610669 „hrvatsko-srpskih“ i 18 028 talijanskih govornika. ${ }^{14}$ Udio onih koji su se izjasnili kao Talijani iznosio je dakle $2,8 \%$ što predstavlja povećanje za neznatnih $0,2 \%$ u odnosu na njihov udio deset godina ranije. Uzrok zadržavanja broja Talijana zasigurno je u već završenom procesu nacionalnih integracija i političkoj stabilizaciji na općinskim razinama za razliku od podataka iz 1880 . i 1900 . godine. To potvrđuje i situacija u Zadru gdje se tada Talijanima izjasnilo čak 9318 građana, što predstavlja $70 \%$ stanovništva, dok je Hrvata i Srba bilo $27 \% .^{15}$

Odnosi zadarskih Hrvata i Talijana u procesima nacionalnih integracija bili su prožeti netrpeljivošću i mržnjom što je nerijetko prerastalo u verbalne, a katkada i u fizičke napade. Treba pritom razlikovati barem tri razine na kojima su se na različite načine demonstrirali ti odnosi: na razini političkih elita odnosi su uglavnom ostajali u granicama uobičajenih političko-rivalskih, zatim odnosi među novinama kao glasilima pojedinih političkih stranaka, dok posebno treba

10 Kažimir Ljubić, Statistika pučanstva u Dalmaciji, Zadar, 1885., 55.; Luigi Maschek (u djelu Repertorio geografico-statistico dei luoghi abitati nel Regno di Dalmazia sulla base di dati ufficiali, Zadar, 1888.) navodi isti broj talijanskih govornika („lingua d'uso“), ali nešto manji broj onih koji govore „srpsko-hrvatskim“ “ezikom - njih 438 727. Ljubić koristi sintagmu „pučanstvo kako obično govori“. Također, ne navodi srpski jezik - ni kao poseban, ni kao „srpsko-hrvatski“ ili „hrvatskosrpski“, odnosno hrvatski ili srpski, kako to navodi Maschek i drugi statističari kasnijih popisa stanovništva.

11 Dinko Foretić, O etničkom sastavu Dalmacije u XIX. stoljeću s posebnim osvrtom na stanovništvo talijanske narodnosti, u: Dalmacija 1870., Zbornik radova, ur. Dinko Foretić, Zadar, 1977., 78.

12 Manfred Makale, Zadnji popis pučanstva u Dalmaciji, Beč, 1912., 43. Pri popisu godine 1900. u Dalmaciji se 565276 osoba izjasnilo govornicima hrvatskog, odnosno srpskog jezika, a njih 15279 talijanskim govornicima.

13 D. Foretić, O etničkom sastavu Dalmacije u XIX. stoljeću s posebnim osvrtom na stanovništvo talijanske narodnosti, 78. Talijanima se u gradu Zadru pri popisu godine 1900. izjasnilo 9135 stanovnika, dok je ostalih bilo 6469.

14 M. MAKALE, Zadnji popis pučanstva u Dalmaciji, 43.

15 Josip Beroš, Zadarsko pitanje, Zadarska revija, 4/1966., 295; Ivo Rubić, Talijani na Primorju Kraljevine Jugoslavije, Split, 1930., 23, 25. 
izdvojiti i dati značaj onome što su suvremenici nazivali ulica - gdje je dolazilo do vrijeđanja, sukoba i obračuna, a čime je zasigurno barem dijelom, odnosno po potrebi, bilo upravljano iz političkih krugova. Akteri ulice nerijetko su bila upravo djeca đačke dobi, što upućuje na zaključak da je politika, odnosno hrvatskotalijanski odnosi, bila česta tema i kod obiteljskog stola što su djeca prenosila i među svoje odnose - na ulicu. ${ }^{16} \mathrm{~S}$ obzirom na to da se tadašnji društveni život odvijao upravo na ulici, od različitih javnih okupljanja (bila ona prosvjedničkog ili podupiralačkog karaktera) pa do običnih svakodnevnih susreta, upravo je ulica bilo mjesto gdje su se neposredno ispoljavali međunacionalni osjećaji. Posebna strana u zadarskim međunacionalnim odnosima bila je državna vlast koju su obje strane prozivale da protiv njih provodi zatorničku politiku štiteći pri tome drugu stranu. ${ }^{17}$

Na zadarskoj političkoj sceni pred kraj Monarhije djelovale su po dvije hrvatske i talijanske političke stranke. Hrvatska stranka nastala je godine 1905 . spajanjem stare Narodne stranke i dijelom članova Stranke prava. Propagatorom stranačke politike može se smatrati Narodni list Jurja Bianchinija, dugogodišnjeg zastupnika Hrvatske stranke. Uz Narodnu stranku, pod vodstvom Ive Prodana, i dalje je djelovala (dalmatinska) Stranka prava koja je imala ogromnu podršku u župničkom kleru, a ideje su širene preko novina Hrvatska kruna pod Prodanovim

16 Ante Tresić Pavičıć, Po Ravnim kotarima, Odabrana djela I, Split, 1999., 457, 458. O svojem iskustvu „zadarske ulice“ početkom 20. stoljeća slikovito svjedoči političar i književnik Ante Tresić Pavičić. Opisuje svoj posjet Zadru kada je pri šetnji gradskim ulicama u društvu s književnikom Rikardom Katalinićem Jeretovim doživio vrijeđanja talijanskih đaka: „(...) Šetasmo se u večer dugo po Calle Larga (?) (Široka ulica), kud je najgušća šetnja Zadrana, oživljujuć uspomene, na Beč, gdje se upoznasmo, i na Praiz, gdje prijateljstvo utvrdismo (...) Bilo je doba kada su talijanski djaci učestali sa svojim demonštracijama proti Hrvatima u Zadru. Svaki parobrod koji bi došao, ako bi zadarski zviždulini saznali, da u njemu ima hrvatskih djaka, sakupili bi se na gatu, pa udri da se kriči. Sada su po zadarskim ulicama po čoporima potrkivali, dovikujuć uvrede svakomu, tko bi hrvatski govorio. Mene su već jednom tvorno napali, prigodom izleta u Dubrovnik na otkriće Gundulićeva spomenika, pa sam predvidjao da će i sada biti uvreda. Ne bi baš imali razloga, da mene napadaju, jer se nisam nikada pokazao neprijateljem talijanske kulture, nego sam marljivo njihove starije i novije pjesnike na hrvatski prevagjao, te uviek zastupao upliv talijanske knjige, kao paralizu za pogubni njemački upliv na hrvatsku književnost. Pisao sam pače i talijanskih pjesama, koje su njihovi listovi sa laskavim opaskama pretiskivali. Ali za to sve ništa ne znadu naši mladi talijančići, nego tko bio da bio, ter hrvatski govori, toga valja vriegjati, makar do potrebe i tvorno napasti i to u glavnom gradu Dalmacije. Opazismo da nas četa zviždulina uzastopce sliedi, ali dakako nastavismo svoje razgovore hrvatski, ne osvrćuć se na njih, kao da ih i nema. Oni stadoše za nama roktati, bekati, meketati, revati, gurikati, misleći tim nas vriegjati, a ponizujuć se sami dotle, da svoj jezik svinjskim zamienjuju. Ja se ograničih na to, da im rečem, da je to više nego oponašanje. Nisu me mudrijaši razumili, i odoše gurikajuć i revajuć, kao mladi oslići u proljeću, kada ih omami vjetar, donoseći preko cvjetnih livada poznati vonj, koji im razdražuje nozdrve.“

17 Uloga austrijskih vlasti u međunacionalnim odnosima u Zadru i općenito u Dalmaciji prelazi okvire ove teme i zaslužuje posebnu raspravu. 
uredništvom. Talijani su politički bili organizirani u Talijanskoj stranci, nastaloj na temeljima stare autonomističke stranke iz 19. stoljeća i na baštini Bajamontijeva La Società Politica Dalmata. Uz nju je kratko djelovala i Pratito Italiano Democratico koju su 1908. osnovali mladi radikali Girolamo Italo Boxich i Ludovico Milcovich nezadovoljni politikom lidera u Talijanskoj stranci. ${ }^{18}$ Ideje i politika Talijanske stranke širene su kroz novine Il Dalmata - svojevrstan pandan Narodnom listu, osnovane 1866. godine, svega četiri godine nakon Il Nazionalea (od 1876. u kroatiziranoj verziji Narodni list). Pratito Italiano Democratico imao je i svoj list Risorgimento u kojem su propagirana radikalna politička stajališta nerijetko prožeta uvredama na račun političkih odnosno nacionalnih protivnika.

U takvim nacionalno polariziranim okolnostima nalazio se Zadar 19. i početka 20. stoljeća. Većinsko talijanski orijentirano gradsko stanovništvo i izborni sustav s jedne strane te nemogućnost političkog dogovora hrvatskih i srpskih stranaka da zajednički uđu u izbornu utakmicu za općinske izbore u Zadru s druge strane omogućavali su da je zadarskom općinom do kraja austrijske uprave upravljala Talijanska stranka. I kad su sve općine u Dalmaciji na valu procesa nacionalne integracije pohrvaćene - kako su govorili suvremenici - odnosno kada su izborima prešle pod vlast hrvatskih (gdjegod i srpskih) stranaka, Zadar je ostao jedina i posljednja talijanska općina u Dalmaciji. Kao takav, bio je simbol talijanstva Dalmacije. Na kraju Prvog svjetskog rata i propasti Austro-Ugarske Monarhije općinsku je vlast 31. listopada 1918. preuzeo načelnik Luigi Ziliotto nakon što su središnje bečke vlasti u svibnju ratne, 1916. godine raspustile zadarsku gradsku upravu upravo zbog njezina protalijanskog karaktera. Ziliotto je tada bio u trećem šestogodišnjem načelničkom mandatu. Posljednji općinski izbori pod austrijskom upravom održavali su se tijekom 1911. godine i bili su osobito zanimljivi pod vidikom hrvatsko-talijanskih odnosa u Zadru. Izbori su održani u godini odlaska namjesnika Nike Nardellija i dolaska na tu dužnost Maria Attemsa, ujedno i posljednjeg austrijskog namjesnika u Dalmaciji. Tih godina političke prilike bile su posebno zaoštrene: na valu politike novog kursa donesene su Riječka i Zadarska rezolucija kao rezultat političkih gibanja u pravcu nacionalnih samoodređenja u Austro-Ugarskoj Monarhiji, a državne vlasti provodile su različita ograničenja političkih sloboda što je kod određenih skupina izazivalo revolt i stvaralo atmosferu političkog i nacionalnog vrenja. Na zadarskoj

18 O prilikama u Zadru pred Prvi svjetski rat vidi više u: Ante BrALIĆ, Zadarski fin-de-siècle Političke i društvene prilike u Zadru i Dalmaciji uoči Prvoga svjetsko rata, Časopis za suvremenu povijest, br. 3, Zagreb, 2007., 731 - 775. O političkim strankama dalmatinskih Talijana vidi više: Mirko ĐinĐIĆ, Političke stranke dalmatinskih Talijana 1886. - 1914. (1918.), Časopis za suvremenu povijest, br. 3, Zagreb, 2012., 679 - 702. 
društveno-političkoj sceni hrvatsko-talijanski odnosi, nakon novokursaške faze koja je ove političke i nacionalne blokove interesno, ali površno i privremeno ujedinila, ulaze u novu fazu zaoštravanja. (To će se posebno manifestirati tijekom Balkanskih ratova 1912. i 1913. godine) Na zadarskim ulicama dolazilo je do čestih međunacionalnih sukoba. Tako je primjerice masovni prolazak članova i simpatizera Hrvatskog Sokola kroz Zadar u kolovozu 1911. na svesokolski slet u Zagrebu iskorišten za manifestiranje hrvatstva u Zadru, a što su Talijani shvatili kao provokaciju na koju su određene skupine odgovorile uvredama i fizičkim napadima. ${ }^{19}$ Gotovo $\mathrm{u}$ sjeni tog i sličnih, ali intenzitetom manjih događaja sa zadarske ulice prošli su općinski izbori za gradsku upravu. Premda su hrvatske političke snage za tu priliku osnovale „Hrvatski međustranački odbor u Zadru“ kao zajedničko tijelo za nastup na izborima, ipak se do izbora odustalo od zajedničkog nauma te se svojim biračima preporučilo da i ne iziđu na izbore. Razlog tomu bile su, prema pisanju Narodnog lista, mnoge nepravilnosti prigodom izbora u dalmatinskim općinama, a koje Namjesništvo nije saniralo. ${ }^{20}$ Kao drugi razlog Narodni list navodi politički dogovor pravaša i zadarskih Talijana po kojem je pravašima prepuštena općinska uprava u Biogradu kao kompenzacija za Zadar gdje su pravaši mogli imati barem dva vijećnika. ${ }^{21}$

Tako je Ziliotto u predvečerje Prvog svjetskog rata i velikih društvenopolitičkih promjena po treći puta postao načelnik jedine talijanske općine u Dalmaciji. Zadarska talijanska općinska uprava i prvaci Talijanske stranke imat će ne beznačajnu ulogu i u poslijeratnim mirovnim konferencijama i cijeloj lobističkoj i medijskoj mašineriji koja ih je pratila. Ziliotto je već 1911. bio potpuno na liniji poslijeratne radikalne iredentističke politike, kada je na svečanoj sjednici prilikom treće izborne pobjede izjavio: „Naša zadaća bit će sačuvati netaknuto nepovredivo talijanstvo našega Zadra, kao što će biti naša težnja postojano se voditi onim visokim osjećajem uljudbe koji nas čini dostojnima velike nacije kojoj pripadamo.“22

Važan čimbenik u zadarskom nacionalno podijeljenom društvu bile su kulturne i društvene organizacije. Onodoban građanski život bio je gotovo nezamisliv bez pripadnosti kulturno-prosvjetnim društvima. Ona su na određen način predstavljala alternativu izravnom političkom djelovanju kroz

19 Sokolaši su tom prilikom organizirali prolazak kroz grad od Kopnenih vrata preko Nove rive. Drugi Zadar, Prolaz Sokola, Treba naći lieka sicilijanskim običajima, Narodni list, br. 64, 12. kolovoza 1911.

20 Obćinski izbori u Zadru, Narodni list, br. 58, 22. srpnja 1911.

21 Rekompensacija u Zadru, Narodni list, br. 74, 16. rujna 1911.

22 Natale Krekich, L'opera amministrativa e politica di Luigi Ziliotto, La Rivista Dalmatica, br. 1-2, Zadar, 1932., 50. 
političke stranke te su imala značajnu ulogu u političkom i uopće društvenom životu. Pripadnost određenom društvu (udruzi) sasvim je precizno označavala i pripadnost određenom društvenom sloju odnosno određenoj nacionalnoj skupini. Nacionalna podijeljenost grada možda se ponajbolje ogledala u pripadnosti određenom društvu, a društveno-politička snaga pojedinog naroda u brojnosti i utjecajnosti pojedinih društava. Zadarski Talijani masovno su bili članovi društava s izrazitim političkim djelovanjem kao Lega Nazionale, Dante Alighieri, Pro Patria i Società di bersaglieri, ali i niza kulturno-karitativnih te sportskih društava. ${ }^{23}$ Hrvati su u razdoblju od polovice 19. stoljeća do kraja Monarhije u Zadru imali gotovo pedeset različitih društava, od kojih su najznačajnija bila Matica dalmatinska, Narodna/Hrvatska čitaonica, Hrvatski akademski klub te Hrvatski Sokol kao najbrojnije hrvatsko društvo s mnogim ograncima i izvan grada. ${ }^{24}$ Djelovanje ovih društava, poput talijanskih, bilo je snažno prožeto političkim idejama. U tom smislu osobito se isticao Hrvatski Sokol koji je, okupljajući šire građanske i pučke slojeve preko kulturno-prosvjetnog i sportskog djelovanja, promicao politiku hrvatskog i jugoslavenskog ujedinjenja. Visokopozicionirani članovi bili su ugledni članovi zadarskog javnog života. Sokol se žestoko protivio talijanskoj autonomističkoj politici što je dovodilo do čestih fizičkih obračuna s neistomišljenicima u Zadru.

Osim u političkoj i kulturnoj sferi, karakter odnosa zadarskih Hrvata i Talijana posebno je bio evidentan i indikativan u tada iznimno važnom društvenom čimbeniku - Crkvi. Kler Zadarske nadbiskupije najvećim je dijelom bio porijeklom sa zadarskih otoka, priobalja i zaleđa, dok je manjim dijelom dolazio iz Zadra ili pak iz drugih istočnojadranskih krajeva, pa čak i iz talijanskih krajeva. Taj odnos hrvatskog i talijanskog klera odgovarao je odnosu Hrvata i Talijana na području Zadra i njegove nadbiskupije. Ali je i utjecaj talijanskog dijela klera odgovarao utjecaju koji su Talijani imali općenito u javnom životu Zadra. U razdoblju austrijske uprave zadarskim nadbiskupima bili su postavljani i stranci i domaći Talijani i Hrvati koji su bili vjerni papi u Rimu i caru u Beču, tako da čelna osoba zadarske (i ujedno dalmatinske metropolitanske Crkve) nije imala odlučujuću ulogu u kreiranju političkih pravaca zadarskog klera

23 A. Bralić, A. Gverić, Dalmazia irredenta - mitološki pogled na povijest, 113 - 115; Dinko Foretić, Društvene prilike u Dalmaciji pred Prvi svjetski rat s osobitim obzirom na radničku klasu, Radovi/Sveučilište u Zagrebu, Filozofski fakultet - Zadar, Razdio historije, arheologije i historije umjetnosti, sv. 2., Zadar, 1963., 230, 231.

24 O hrvatski društvima u Zadru vidi više: Vjekoslav MAšT rović, Hrvatska društva u Zadru (18481920), u: Zadar. Geografija-ekonomija-saobraćaj-povijest-kultura. Zbornik radova, ur. Jakša Ravlić, Zagreb, 1964., 469 - 486. 
u žrvnju nacionalnih integracija. Drugim riječima, ono svećenstvo koje je politički djelovalo, djelovalo je ili sâmo za sebe ili u okviru određenih manje ili više formalnih političkih organizacija. Ipak, uloga nadbiskupa bila je vidljiva u pozicioniranju svećenstva: isključivo njegova ingerencija u postavljanju na određene službe omogućavala je da pojedinci i njihov rad više dođu do izražaja u javnom životu.

Kroz pitanje staroslavenskog jezika u liturgiji Crkva je posredno bila aktivnim sudionikom aneksionističko-autonomističkih sukoba. Od papinske bule Grande Munus (1880.) kojom je Lav XIII. potvrdio korištenje staroslavenskog jezika u liturgiji, pitanje glagoljice i borba za njezinu emancipaciju postalo je prvorazrednim političkim pitanjem oko kojega su se lomila koplja od najviših crkvenih i političkih razina do onih najnižih. I u ovom slučaju, općenito uzevši, suprotstavljene strane opet su bile postavljene na nacionalnim osnovama: Hrvati su branili pravo na glagoljicu u liturgiji, dok su Talijani tu iznimnu povlasticu (privilegio) smatrali sredstvom u političkoj borbi. Osim kod pitanja glagoljice, politička sfera prešla je u crkvenu i kod pitanja kadroviranja na nadbiskupskoj stolici tijekom prisilne ostavke nadbiskupa Mate Dujma Dvornika u kasnu zimu i proljeće 1910. Hrvati su isticali Dvornikovu naklonost prema glagoljici kao navodni razlog za iznuđenu ostavku, ${ }^{25}$ dok su Talijani opovrgavali te tvrdnje ističući da je riječ o jeftinom političkom potkusurivanju te da je Dvornik svrgnut sa službe zbog kršenja crkvenih propisa i izražene italofobije. ${ }^{26}$ Situacija se toliko otela kontroli da je primjerice nadbiskup Dvornik bio metom bezočnih

25 Narodni list u uvodniku „O glagoljici“ br. 14, 16. veljače 1910., o tome piše: „Akoprem službena štampa to poriče, očito je, da je N. P. nadbiskupu Dvorniku bila uzeta jurisdikcija ne radi stanja njegova zdravlja nego radi glagoljice, za koju se je on živo zalagao." U nastavku prenosi i pisanje bečkih novina Neue F. Presse o istom slučaju: „Uz veliko značenje, koje imadu dogadjaji u Dalmaciji i u primorju za politiku monarkije, vrlo je važna činjenica, da su hrvatski narodni osjećaji, i u jednog nadbiskupa mnogo jači, nego vjera u dužnosti poslušnosti prema papi. Nacionalizam imade ondje na jugu države na opasnom tlu Dalmacije, a jamačno i Istre i istarskih otoka, snagu koja je postala jača, nego li snaga klerikalizma. Pa i jedan nadbiskup gubi svoje mjesto ne kao mučenik vjere, nego kao mučenik svoga hrvatskog mišljenja.“ Da li baš narodni uspjeh Talijana na crkvenom polju?, Hrvatska Kruna, br. 16, 12. veljače 1910. Prodanova Hrvatska Kruna izravno je optužila Talijane za Dvornikovu smjenu: „Talijani se napokon imaju da pohvale jednim velikim 'nacionalnim' kako kažu uspjehom. Uspjelo im je da sa uprave zadarske Nadbiskupije bude maknut N. P. Nadbiskup Dvornik. U veselju se iztiču ovi naši talijanaši. Baš je da se čovjeku zgrsti. Ovi naši svedjerni protivnici, ako igda to se u ovoj prigodi pokazaše što su. I tigri i hijene.“

26 L'arcivescovo senza diocesi, Risorgimento, br. 69, 3. veljače 1910. Na istom mjestu uvodničar objašnjava razloge svojih protivljenja nadbiskupu Dvorniku: „(...) Mi smo ga napadali samo zbog nacionalne štete koju nam je nanosio, dozvoljavajući protiv svakog prava korištenje glagoljice u latinskim crkvama i zbog hrvatskog domoljubnog stava kojega je zauzeo bio u pravu ili u krivu kao i zbog istaknute italofobije u nekim njegovim postupcima.“ 
provokacija ruganjem i urlanjem talijanske djece pred nadbiskupskom palačom. ${ }^{27}$ Dvornikova smjena bila je i tema u Dalmatinskom saboru. Pravaški zastupnik Mate Drinković grmio je sa saborske govornice da je „neprijateljima hrvatskog naroda uspjelo da ga maknu (Dvornika, op. A.G.) i po svoj prilici, doći da upravlja ovom velikom nadbiskupijom čovjek koji nije ni najmanje prijateljski raspoložen ni prama našem narodu, niti prama njegovim svetinjama“. ${ }^{28} \mathrm{I}$ Dvornikov nasljednik, dotadašnji šibenski biskup, Olibljanin Vinko Pulišić, osjetio je gorčinu službe upravo kroz međunacionalne odnose u Zadru. Svoju službu zadarskog nadbiskupa i dalmatinskog metropolita u vrijeme raspada Austro-Ugarske Monarhije i talijanske okupacije ocijenio je kao najtežu u Dalmaciji ,jer se neprestano nalazi između dvije vatre“. ${ }^{29} \mathrm{O}$ odnosima zadarskih Hrvata i Talijana govorio je kao o "due elementi che si guardano in cagnesco“. 30

Općenito uzevši, kler Zadarske nadbiskupije je u nacionalnim osjećajima, a potom i u političkim stajalištima, bio podijeljen po istom principu i u sličnom omjeru kao i ostali dio društva. Valja pritom istaknuti i činjenicu da je velik dio župničkog klera odigrao izuzetno važnu ulogu kao aktivni promotor pravaških ideja odnosno politike Stranke prava među seoskim stanovništvom, što je dodatno produbilo jaz prema političkim protivnicima - autonomašima, ali i prema dalmatinskim Srbima.

Iz prethodno iznesenog može se zaključiti da je zadarsko društvo tijekom razdoblja formiranja modernih nacija druge polovice 19. i početka 20. stoljeća bilo duboko podijeljeno. Razlog podijeljenosti jesu stubokom različiti ideološkopolitički koncepti razumijevanja pozicije vlastite nacionalne skupine i slijedom toga konstitucionalnosti Dalmacije kao povijesne i administrativne cjeline. Podijeljenost dalmatinskog društva seže još u doba mletačke uprave i formiranja

27 Hrvatska Kruna, br. 15, 10. veljače 1910. „Gadno. Sinoć koja stotina dječurlije i mladjarije, a među njima, kako nas uvjeravaju članovi ovdješnjeg družtva „Libera“, o kojem svak zna kakvo je i kakvim duhom diše; na povratku s neizbježive f $\mathrm{r}$ a j e prvog dana korizme, prošla je obhodno izpod nadbiskupske polače, pjevajuć u žalobnom tonu, sa bakljicama, a proti komu to, već se razumije (...).“

28 Hrvatski Sabor u Zadru (XLII zasiedanje), 25.a Sjednica, dne 1 veljače, Hrvatska Kruna , br. 12, 3. veljače 1910. Drinković je pritom mislio na Giovannija Borzattija, od godine 1907. pomoćnog biskupa u Zadru. Njegove slutnje nisu se, međutim, obistinile jer Borzatti kao autonomaš i nepoznavatelj hrvatskog jezika tada nije bio odgovarajući kandidat za nadbiskupsku službu ni bečke vlade ni rimske kurije.

29 Antonio ScotтÀ, I territori del confine orientale italiano nelle lettere dei vescovi alla Santa Sede 1918.-1922., Trieste 1994., 439. Vinko Pulišić u pismu Federicu Tedeschiniju, zamjeniku državnog tajnika Svete Stolice, 27. studenog 1919.

30 A. ScоттÀ, I territori del confine orientale italiano., 418, Vinko Pulišić u pismu Federicu Tedeschiniju, 14. ožujka 1919. 
vladajućeg patricijsko-građanskog sloja $s$ jedne strane i njemu podčinjenog seljačkog, kolonatskog stanovništva $s$ druge strane. Patricijsko-građanski sloj bio je dominantan na svim društvenim razinama i tako je devetnaestom stoljeću ostavio u nasljeđe jak društveni utjecaj koji se prije svega manifestirao u talijanskom jeziku kao službenom i kulturno-javnom jeziku Dalmacije. Zadar je kao upravni i uopće svekoliki centar Dalmacije pod austrijskom upravom bio poprištem i žarištem nacionalnih i političkih sukoba. Prvi svjetski rat i zadnje dane Austro-Ugarske Monarhije zadarske su političke skupine dočekale $s$ visoko razvijenim modelima realizacije nacionalnih stremljenja, u potpunosti oprečnima, a što je bilo polazište međunacionalnim i osobnim sukobima.

\section{ZADAR 1918. - PROPAST MONARHIJE I TALIJANSKA OKUPACIJA}

Objava rata Italije Austro-Ugarskoj 23. svibnja 1915. označava početak nove faze u hrvatsko-talijanskim odnosima u Zadru: dalmatinskim Hrvatima u borbi za Cara i Monarhiju novi - i zbog savezničkog vjerolomstva - omraženi neprijatelj postaje Italija - Gran Madre dalmatinskih Talijana. Time će i odnosi Hrvata i Talijana u Zadru ponovno postati napeti. Mada je prve noći nakon objave rata zabilježen manji izgred uperen protiv jednog obrtnika - talijanskog državljanina ${ }^{31}$ - tijekom rata u Zadru nije bilo ozbiljnijih međunacionalnih sukoba. Oni će nastupiti tek okončanjem rata i okupacijom grada talijanskih mornaričkih snaga. Talijanski konzul u Zadru Antonio D’Alia, zbog objavljenog neprijateljstva svoje zemlje prema Austro-Ugarskoj, već je sutradan nakon objave rata napustio Zadar, ${ }^{32}$ a zadarsko općinsko vijeće sa Ziliottom na čelu u poklonstvenom posjetu namjesniku Attemsu izrazilo je „nepomućene osjećaje najdublje odanosti i vjernosti prama previšnjem Vladaru i državi“ ${ }^{33}$ Neslužbeno glasilo Talijanske stranke Il Dalmata već je i prije Ziliottova iskaza vjernosti Attemsu objavilo članak o lojalnosti i dubokoj privrženosti dalmatinskih Talijana Caru državnim institucijama. ${ }^{34}$

Ipak, kurtoazne izjave nisu imale učinka pred činjenicom da glavnim gradom pokrajine u jeku borbi s Italijom upravlja Talijanska stranka u kojoj su djelovali

31 Viesti iz Grada i okolice. Izkazi, Narodni list, br. 42, 26. svibnja 1915. U noći s 23. na 24. svibnja 1915. razbijena su stakla na brijačnici talijanskog državljanina, izvjesnog Glorie. To je bio povod da vlasti organiziraju stražu pred talijanskim konzulatom. Viesti iz Grada i okolice. Izkazi, Narodni list, br. 42, 26. svibnja 1915.

32 Viesti iz Grada i okolice. Talijanski konzuo, Narodni list, br. 42, 26. svibnja 1915.

33 La Cronaca. Manifestazione della rappresentanza cittadina, Il Dalmata, br. 43, 29. svibnja 1915.

34 La Cronaca, Il Dalmata, br. 42, 26. svibnja 1915. 
mnogi pojedinci koji su u vezi jadranskog pitanja zastupali ideje radikalnije od tadašnje vlade $u$ Rimu. Osim toga, $u$ prilog podizanju ratnog morala pučanstva i vjere u pobjedu nije išla činjenica da se dalmatinski Hrvati bore za Monarhiju dok Zadrom upravljaju Talijani čiji su sunarodnjaci s druge strane Jadrana postali ratni neprijatelji Monarhije. Stoga su središnje vlasti u Beču 29. svibnja sljedeće godine raspustile zadarsku općinu i za povjerenika postavile visokopozicioniranog činovnika u Namjesništvu, dvorskog savjetnika Hrvata Matu Škarića. ${ }^{35}$ Dalmatinsko namjesništvo nastavilo je s raspuštanjem i nekih talijanskih društva u Zadru. ${ }^{36} \mathrm{U}$ travnju je izišao i posljednji broj dugovječnog Il Dalmate, s obrazloženjem da se direktor i urednik lista Gaetano Feoli „morao udaljiti iz Zadra te se ne može predvidjeti koliko će potrajati njegovo izbivanje “. ${ }^{37}$ Vlasti nisu samo derogirale općinsku upravu, već su protiv istaknutih dalmatinskih Talijana provodile različite oblike zakonom predviđenih prisilnih mjera u cilju sprječavanja mogućih neprijateljskih poduhvata. Većina politički aktivnih čelnika optužena je za veleizdaju. Roberto Ghiglianovich već je nakon ulaska Italije u rat prebjegao u Rim gdje je lobirao za rješenje jadranskog pitanja u korist Italije. Nekolicina istaknutih zadarskih talijanskih političara i javnih djelatnika internirana je ili konfinirana izvan Dalmacije. ${ }^{38}$ Vlasti su iste mjere provodile i protiv jugoslavenski orijentiranih pojedinaca i ustanova koji su zagovarali razbijanje Monarhije i ujedinjenje sa Srbijom. ${ }^{39}$ Takve snage $u$ Zadru ipak nisu bile značajne koliko u drugim dalmatinskim sredinama. Tako su primjerice u Zadru do travnja 1916. bila raspuštena svega dva netalijanska društva: Hrvatski akademički klub i Srbski sokol, dok je istovremeno u ostalim dalmatinskim mjestima bilo raspušteno 51 društvo jugoslavenske orijentacije. ${ }^{40}$

35 Viesti iz Grada i okolice, Narodni list, br. 43, 31. svibnja 1916.

36 Viesti iz Grada i okolice, Narodni list, br. 45, 7. lipnja 1916. Tom prilikom raspuštena su društva Nicolò Tommaseo i Talijansko političko društvo u Dalmaciji. Međutim, od početka rata do travnja 1916. u samom Zadru raspušteno je još 13 talijanskih društava. Razpuštena društva u Dalmaciji, Narodni list, br. 29, 12. travnja 1916.

37 Il Dalmata, br. 28, 8. travnja 1916. Feoli je, naime, bio interniran.

38 Destinacije interniraca bile su ponajviše po dalmatinskim gradovima, a konfinacije su se provodile diljem Austrije (Graz, Leibnitz, Beč i manja mjesta). Od istaknutih talijanskih pojedinaca bili su konfinirani Natale Krekich, Amato Talpo, Gaetano Feoli - urednik Il Dalmate, Pietro Domiacussich, Manfredo Persicalli i drugi. Luciano Monzali, Italiani in Dalmazia 1914-1924, vol 2. Firenze, 2007., 8, 9; Antoni D’Alia, La Dalmazia nella storia e nella politica nella guerra e nella pace, Roma, 1928., 140 - 148. O odnosu vlasti prema Talijanima u Zadru za vrijeme Prvog svjetskog rata vidi više u: Ante BRALIĆ, Zadar u doba Prvoga svjetskoga rata, Doktorska disertacija, Zadar, 2005., 126 - 153.

39 Josip BEroš, Dalmacija pod terorom posljednje austrijske Attemsove administracije, Zadarska revija, XIII, br. 6, Zadar, 1964., 574 - 577.

40 Razpuštena društva u Dalmaciji, Narodni list, br. 29, 12. travnja 1916. 
Rat je dakle hrvatsko-talijanske odnose u Zadru doveo u neutralnu fazu: vladine mjere suzbijanja mogućeg protudržavnog djelovanja na bilo kojoj razini, bilo s talijanske bilo sa strane jugoslavenskih snaga, uzrokovale su mirovanje na razini odnosa zadarskih Hrvata i Talijana. Tek će nakon smrti cara Franje Josipa (21. studenog 1916.) doći do liberalizacije političkog života, što će i u Zadru omogućiti oživljavanje predratnih međunacionalnih borbi. Sada međutim, zbog propasti Monarhije, međunacionalne borbe vodit će se sa sasvim drugačijih polazišta negoli prije rata.

Tako su se političke snage zadarskih Hrvata (i Srba) te Talijana ponovno pojavile na političkoj sceni: Talijani su, doduše oprezno, predvođeni Ziliottom u veljači 1918. nanovo pokrenuli rad Società del Casino te bez javnih političkih aktivnosti čekali neminovan kraj rata. Na valu masovnih podrški Svibanjskoj deklaraciji hrvatski i srpski političari sazvali su u Zadru u ožujku 1918. narodnu skupštinu koja je iznjedrila rezoluciju o pravu na samoodređenje Srba, Hrvata i Slovenaca unutar Monarhije. ${ }^{41}$ Kraj rata i kolaps Austro-Ugarske zadarski političari dočekali su s neskrivenim zadovoljstvom: Hrvati i Srbi već su tijekom listopada osnovali Odbor Narodnog vijeća, a Talijani su 27. i 28. listopada zbili redove za nadolazeće događaje organizirajući neformalne sastanke. ${ }^{42}$ Zadnjeg dana listopada 1918. u Zadru se derogiraju pokrajinske austrijske vlasti. Nakon što je namjesnik Attems proglasom obavijestio Dalmatince da je njegova zadaća samo omogućiti nesmetanu predaju vlasti, 31. listopada u Namjesništvo dolaze politički predstavnici i Hrvata i Talijana da zajedno preuzmu vlast. ${ }^{43}$ Istog dana Ziliotto i njegovo u svibnju 1916. suspendirano Gradsko vijeće preuzeli su upravu općine. Kad se obraćao puku na trgu pred općinskom upravom, Ziliotto je pozivao na „bratstvo koje mora da vlada medju gradjanima Jugoslavenima i Talijanima“. ${ }^{44}$ Gradske ulice bile su pune razdraganog svijeta. Okićeni zastavama u povorkama, pjevali su i klicali i Hrvati i Talijani. S upravnih institucija skinuti su amblemi crno-žute monarhije, a na Gradskoj straži bile su izvješene srpska, talijanska i hrvatska zastava. Jedna grupa spalila je tek podignuti spomenik austrougarskoj mornarici Zaštitna lagja okovana na Novoj rivi pokraj zgrade Pošte. Iskazi veselja nastavili su se i sutradan navečer kada je povorka Hrvata

41 Tekst Rezolucije vidi u: Ferdo Šıšıć, Dokumenti o postanku Kraljevine Srba, Hrvata $i$ Slovenaca 1914.-1919., Zagreb, 1920., 126, 127.

42 Antonio D'Alia, La Dalmazia nella storia e nella politica nella guerra e nella pace, 153. Talijanski konzul u Zadru Antonio D’Alia kazuje da je „između 27. i 28. Ziliotto sazvao u Zadru talijanske starješine kako bi im kazao da budu spremni za neminovne događaje koji bi trebali slijediti.“”

43 Predaja Namjesništva, Narodni list, br. 51, 31. listopada 1918. To su bili Silvije Alfirević, Josip Cortelazzo (Jablanović) i Luigi Ziliotto.

44 Preuzimanje obćine, Narodni list, br. 51, 31. listopada 1918. 
$s$ hrvatskom trobojnicom prošla gradom pjevajući domoljubne pjesme i kličući pred stanovima narodnih zastupnika, a nakon njih formirala se talijanska povorka u kojoj se „... pjevalo (se) i provokatornih talij. pjesama iz dobe najžešćih prošlih borba. I ona t. zv. del si ${ }^{4}{ }^{45}$

Pripadnici talijanske elite u prostorijama društva Casino osnovali su 3. studenog Fascio nazionale - udrugu izrazito političkog karaktera. Tom prilikom Ziliotto je uime udruge objavio proglas "Talijanima Dalmacije“ u kojem osvješćuje važnost trenutka: propast Austrije kao dugogodišnjeg neprijatelja Talijana i nadolazeće ujedinjenje Dalmacije $s$ Italijom. Sadržaj proglasa uznemirio je hrvatske građane isto kao i drugi proglas koji je Ziliotto kao načelnik dva dana kasnije uputio građanima Zadra u kojem je proglasio pripojenje Zadra Italiji. ${ }^{46}$ Ivo Prodan u Hrvatskoj Kruni komentirao je ove proglase kao iznenađenje zbog kojega su zadarski Hrvati i Srbi „ostali osupnuti“. Dodaje da je nakon „oslobođenja“ i zajedničkog slavlja koje ga je pratilo, nastala neka „utakmica“ između Talijana i Hrvata i Srba u Zadru. ${ }^{47}$ Premda nisu imali juridičkih osnova, Ziliottovi proglasi u građanstvo su unijeli zbunjenost i nemir te su bili prvi poslijeratni javni akti iredentističke politike u Zadru i kao takvi su imali dalekosežne posljedice za nadolazeće sve lošije međunacionalne odnose u gradu kojim će narednih četvrt stoljeća upravljati Italija. Početak talijanske vlasti nad Zadrom možda najslikovitije označava upravo uplovljavanje torpiljarke 55AS talijanske ratne mornarice koja je u zadarsku luku uplovila 4. studenog 1918. nekoliko minuta nakon 14,30 sati. Naime, temeljem Ugovora o primirju između Italije i Austro-Ugarske, potpisanog u Villa Giusti pokraj Padove dan ranije, Italija je kao članica pobjedničkih sila imala pravo na okupaciju evakuiranih austrijskih područja. ${ }^{48}$ Iako okupacija austrijskih područja nije mogla ni smjela prejudicirati rješenja mirovnih konferencija, ipak je u slučaju Dalmacije Italija učinila sve da si osigura što bolju početnu poziciju na nadolazećim konferencijama mira. U tom smislu i sama činjenica dolaska torpiljarke u Zadar nekoliko minuta prije nastupa primirja (ono je trebalo nastupiti 24 sata nakon potpisa Ugovora o primirju, to jest u 15,00 sati 4. studenoga) korištena je kasnije od talijanske strane kao argument da je Zadar, tobože, osvojen u ratu (de iure belli). Italija nije poštovala ni članak 6. Ugovora o primirju koji je određivao da privremeno zadrže postojeće lokalne

45 Obhod po gradu. Ovacije zastupnicim, Hrvatska Kruna, br. 41, 2. studenog 1918.

46 Due proclami, La voce Dalmatica, br. 2, 13. studenog 1918.

47 Novi položaj. Dva proglasa načelnika D. ra Ziliotta. Manifestacije, Hrvatska Kruna, br. 42, 9. studenog 1918.

48 Ugovor vidi u: Ferdo Šıšıć, Dokumenti o postanku Kraljevine Srba, Hrvata i Slovenaca 1914.-1919., Zagreb, 1920., 221 - 224. O Ugovoru o primirju više vidi u: Bogdan KRIZMAN, Ugovor o primirju savezničkih i udruženih sila s Austro-Ugarskom (3.XI.1918.), Pomorski zbornik, sv. 7, Zadar, 1969. 
vlasti. Činjenica da su saveznici prepustili upravo Italiji da zaposjedne austrijska područja u Dalmaciji upućuje na zaključak njihove prešutne suglasnosti za realizaciju odredbi Londonskog ugovora i prije mirovnih konferencija.

Bolje obaviješteni pojedinci u Zadru - i Talijani i Hrvati - pred kraj rata već su imali informacije da će Italija u ime saveznika okupirati Dalmaciju. U svojim sjećanjima na te dane Juraj Bianchini svjedoči da se krajem rujna 1918. znalo da će Italija u ime Antante zaposjesti sjevernu Dalmaciju te da su „naši ljudi iz inozemstva“ inzistirali da se Talijane mirno dočeka jer dolaze kao saveznici za uspostavu javnog reda i mira dok bi svaki otpor „škodio svetoj stvari našega narodnog ujedinjenja“. Bianchini dodaje da je ipak malo tko vjerovao u prijateljstvo Talijana te da su mnogi bili spremni silom odbiti talijanske mornare, ali su se unatoč tomu politički vođe odlučili za miran doček..$^{49}$ Nema sumnje da su i zadarski Talijani, preko Ghiglianovicha i ostalih prebjega koji su se još uvijek nalazili u Italiji, unatoč strogoj cenzuri imali informacije o postupanju Italije nakon kapitulacije Austrije. Međutim, držali su se vrlo oprezno čekajući do kraja rasplet situacije. Stoga je Fascio Nazionale osnovan tek nekoliko dana nakon što je bilo evidentno da je Monarhija propala, odnosno istog dana kada su zaraćene strane potpisale primirje. Već 11. studenog 1918. pokrenuli su novine La voce dalmatica koje je u izrazito iredentističkom duhu uređivao Gaetano Feoli, nekadašnji urednik Il Dalmate. Politika vlade u Rimu prema Dalmaciji (predsjednika Orlanda i ministra vanjskih poslova Sonnina) bila je brza provedba odredbi Ugovora o primirju, a s obzirom na mjesno slavensko stanovništvo, vojska je dobila upute da pravično upravlja čvrstom rukom, ali sa svim mogućim respektom prema stanovništvu kako bi vjerovalo da su Talijani došli kao osloboditelji, a ne kao ugnjetavači. ${ }^{50}$ Upravo u skladu s tom preporukom bilo je postupanje zapovjednika torpiljarki koje su prve uplovile u zadarsku luku. I Hrvati su - prema novinskim napisima - dočekali prve torpiljarke onako kako su im preporučili njihovi politički prvaci. Prema tim izvorima, talijanski vojnici su prilikom dolaska izvikivali parole poput „Evviva la Jugoslavia!“ te čak tražili da se pjeva „Lijepa naša“, a Hrvati su uz sugrađane Talijane hrvatskim i srpskim zastavama dočekali torpiljarke. Zapovjednika torpiljarke 55AS Rina Matteuccija sokolaši su, navodno, na rukama nosili gradom davši mu u ruke hrvatsku zastavu. Kad je povorka stigla pred zgradu Namjesništva, s balkona ih je na talijanskom jeziku pozdravio podnamjesnik Josip Cortellazzo (Jablanović).

49 Juraj Bianchini, Prva dva mjeseca italijanske okupacije Dalmacije, Almanah Jadranske straže za 1928-1929, Beograd, 1929., 97 - 101.

50 Maria Grazia Melchionni, La vittoria mutilata, Problemi ed incertezze della politica estera italiana sul finire della Grande guerra (ottobre 1918 - gennaio 1919), Roma, 1981., 80. 
Također, prema pisanju novina, okupilo se preko 5000 ljudi čineći povorku od zavoda sv. Dimitrija do Hrvatske čitaonice na drugoj strani poluotoka. ${ }^{51} \mathrm{Hrvatski}$ politički vođe zaista su prvih dana okupacije uvjeravali svoje sunarodnjake da Talijani dolaze kao saveznici te da ih kao takve treba primiti. Silvije Alfirević, kao tajnik Odbora Narodnog vijeća SHS u Zadru, na narodnom je skupu u dvorištu Hrvatskog sokola 5. studenog pozivao na red i mir, civilizirano i dostojanstveno ponašanje. Juraj Bianchini, zastupnik Hrvatske stranke, u Narodnom listu prvih je dana okupacije stalno pozivao na mir, ističući primjere međunacionalnih srdačnih odnosa. ${ }^{52}$ Isto je činio i pravaški vođa Ivo Prodan u svojoj Hrvatskoj Kruni. ${ }^{53} \mathrm{U}$ početku se vjerovalo da je okupacija tek privremenog karaktera te da je konačno uređenje isključivo $u$ ingerenciji mirovne konferencije. Zbog toga su se velike nade polagale $u$ američkog predsjednika Wilsona.

U prvim izvješćima svojim zapovjedništvima u Veneciji i Rimu zapovjednici torpiljarki ističu da su bili entuzijastično primljeni od Zadrana, ali ipak ne navode da su i „Jugoslaveni“ sudjelovali u dočeku na način kako to navodi Bianchini u Narodnom listu. Pietro Starita, zapovjednik ratnog broda Audace, koji je u Zadar stigao 7. studenoga, navodi da ih je dočekalo mnoštvo građana s brojnim zastavama od kojih su tek poneke bile jugoslavenske („poche jugoslave“), ${ }^{54}$ premda „cijeli grad bijaše okićen jugoslavenskim i talijanskim zastavama “. 55 Izvjesno je da su tekstovi u hrvatskim novinama - o srdačnom dočeku talijanske vojske od strane Hrvata (i Srba) - služili u svrhu svrstavanja na stranu saveznika - ratnih pobjednika. Takvo postupanje upravo je na tragu preporuka vlasti novoosnovane Države $\mathrm{SHS}^{56} \mathrm{i}$

$51 \quad$ Manifestacije jugoslavenstva u Zadru, Narodni list, br. 52, 7. studenog 1918.

52 Manifestacije jugoslavenstva u Zadru, Narodni list, br. 52, 7. studenog 1918. Bianchini na istom mjestu u rubrici „Viesti iz grada i okolice“ navodi: „Okupacija Zadra od strane talijanske vojske sliedila je sasvim mirno. Javni red i mir nije bio poremećen. Hrvatsko i srbsko pučanstvo Zadra ponielo se je baš uzorno, slušalo je svoje vodje i pokazalo se je jako dišiplinirano. Nije se ni osvrćalo na pojedina izazivanja, sigurno da je okupacija prelazna i da mirovni kongres ima i u ovom pitanju zadnju rieč proti kojoj nema priziva. Mi najživlje preporučujemo našim ljudima, da se i unapried ovako uzorno ponašaju i da se pokažu dostojni velike Jugoslavije, kojoj oni pripadaju i do vieka će pripadati. Živio Wilson i živila Jugoslavija! Živila naša saveznica Italija! Vojska i oficiri talijanski u Zadru nisu do sada dali povoda nikakovoj tužbi jugoslavenskog pučanstva. Naši prvaci koji s oficirima dospješe u doticaj kažu da su ljudi vrlo fini i bistre pameti, prožeti pravim duhom slobode i jednakosti, koji razume faktični položaj i Zadra i Dalmacije (...).“

53 „Mir i red“, Hrvatska Kruna, br. 42, 9. studenog 1918. (Uvodnik).

54 Archivio storico della Marina Militare, Roma (dalje skraćenicom: ASMM), busta „Millo“. Startia al Comando flotiglia C.T.A.A., Raporto di missione a Zara, 8. studenog 1918.

55 ASMM, busta „Millo“. De Boccard al Comando in Capo Dip. Venezia, Raporto di missione, 5. studenog 1918.

56 „(...) Mir i red to je odluka i želja naše centralne vlade u Zagrebu, Zadru i pokrajinske u Spljetu te našeg mjestnog odbora: D.ra Cortellazza i D.ra Makieda i dr. Mir i red to je tolikrat opetovana naša preporuka (...)“, Mir i red, Hrvatska Kruna, br. 42, 9. studenog 1918. 
razumljivo je s obzirom na to da su se Hrvati borili za Monarhiju koja je kapitulirala te su u novonastaloj situaciji tražili najpovoljnije rješenje nacionalnog pitanja. ${ }^{57}$ Međutim, desetljećima napeti i sukobima opterećeni međunacionalni odnosi nisu ostavljali odviše mogućnosti za prijateljsko povjerenje. $\mathrm{K}$ tomu su i odredbe Londonskog ugovora učvršćivale u uvjerenju da Italija zauzima Zadar i Dalmaciju iz političkih motiva, a ne radi sigurnosnih i aprovizacijskih razloga povjerenima joj Ugovorom o primirju. Na to jasno upućuju izvješća zapovjednika ratnih brodova. U prvom izvješću zapovjedništvu u Veneciji kapetan korvete torpiljarke 55AS Felice De Boccard izvještava da je dolaskom u grad proglasio okupaciju grada na što $\mathrm{mu}$ je istog dana Jerko Machiedo $\mathrm{u}$ ime Zemaljske vlade u Splitu uložio protestnu notu. ${ }^{58}$ Dodaje da su predstavnici jugoslavenskih vlasti naizgled srdačni i odani, ali su zapravo neprijateljski nastrojeni. Pripadnici stranke koja je „,costituito dalla nazionalità jugoslava“ jesu mnogi demobilizirani vojnici i pobunjenici koji drže stvarnu vlast, a potpomognuti su policijskim snagama - navodi De Boccard. Takvi su izvan kontrole pokrajinskih vlasti u bivšem Namjesništvu, pogotovo oni izvan grada, u selima, gdje spremaju subverzivna djelovanja. Među Talijanima to uzrokuje veliki strah i zbog toga je De Boccard bio uvjeren da njihovim dolaskom politička situacija postaje izrazito ozbiljna. Stoga je od nadređenih zatražio slanje još jednog ratnog broda i jednog bataljuna vojnika. Dodao je da će u tom slučaju odrediti da predstavnici "Governo jugoslavo nazionale“ premjeste svoje središte izvan grada. ${ }^{59}$

Istovremeno s okupacijom Zadra Italija je mornaričkim snagama intenzivno pristizala i u druga obalna i otočka mjesta sjeverne i srednje Dalmacije gdje bi „proglašavala“ okupaciju. Temeljem tih informacija i stanja u Zadru, gdje je vojska osim podjele živežnih namirnica preuzimala i vojnu upravu, hrvatske političke snage započele su snažnu kampanju otpora. $S$ otporom su rasli razni oblici ograničavanja slobodâ pojedinaca i udruga, što se pogotovo očitovalo nakon što je vrhovni zapovjednik talijanske vojske general Diaz 19. studenog 1918. imenovao viceadmirala Enrica Milla guvernerom okupiranih područja

57 U nastojanjima da osujete rješenje jadranskog pitanja u korist Jugoslavije, vođe Talijanske stranke u Dalmaciji u svjetsku javnost često su plasirali teze da je Zemaljska vlada SHS u Splitu tek „čedo Austrije“ te „da je ta vlada prostim udarom i pristajanjem Austrije prisvojila i afirmirala svoju moć nad namjesništvom i zemaljskim uredima u Zadru“. Ghiglianovich u intervjuu listu „Il giornale d'Italia“. Prenio Narodni list, br. 58, 5. prosinca 1918. u članku „Na adresu Dr Giljanovića“.

58 Notu vidi u: Ferdo Šıšıć, Dokumenti o postanku Kraljevine Srba, Hrvata i Slovenaca 1914.-1919, 227, 228.

59 ASMM, busta „Millo“. De Boccard al Comando in Capo Dip. Venezia, Raporto di missione, 5. studenog 1918. 
u Dalmaciji. ${ }^{60}$ Bianchini je u Narodnom listu Talijane nazivao tuđincima koji „hoće opet da stave svoju stopu na ovu našu divnu ali nesretnu zemlju“, ${ }^{61}$ dok je raspoloženje među Zadranima ocijenio kao podijeljeno na „dvie jake struje (koje) stoje jedna protiv druge “.$^{62}$ Do prvog većeg sukoba Talijana i Hrvata došlo je 30. studenog kada su u Zadar doplovila dva saveznička japanska ratna broda. Hrvati su u povorci sa zastavama svih savezničkih snaga krenuli pred brod kako bi pjesmama i aklamacijama iskazali hrvatstvo, odnosno jugoslavenstvo Zadra. Povorku je presrela grupa talijanskih građana koja ih je verbalno i fizički napala. Intervenirale su i redarstvene snage, ali bez puno uspjeha. Prema pisanju novina, bilo je i ranjenih. ${ }^{63} \mathrm{U}$ izvješću nadređenima zapovjedništvima u Udinama i Rimu o tom sukobu guverner Millo navodi da su Hrvati pjevali hrvatsku himnu - „mai suonato a Zara neppure durante il dominio austriaco“. Dodaje da inače organiziraju okupljanja i govore na palubama savezničkih brodova u svakoj prilici njihova uplovljavanja u zadarsku luku. ${ }^{64}$ Millo je donio odluku o zabrani demonstracija bez prethodne dozvole. ${ }^{65}$ Tih dana novine su zabilježile i premetačine u Hrvatskoj čitaonici, Sokolu i Akademskom klubu. ${ }^{66}$

Uslijedile su potom i diplomatske aktivnosti zadarskih Hrvata: Zemaljski odbor i Odbor Narodnog vijeća SHS u Zadru uputili su početkom prosinca brzojav američkom predsjedniku Wilsonu i predsjedniku francuske vlade Clemenceau u kojem mole intervenciju za sjedinjenje Zadra s Jugoslavijom. ${ }^{67}$ U Hrvatskoj čitaonici gostovala je neka grupa Amerikanaca kojima je domaćin bio Josip Cortellazzo koji im je govorio o prilikama u Zadru. ${ }^{68}$ „Prijelomna“ 1918. u Zadru završila je tako u nacionalno podijeljenom ozračju, iako se početkom studenog činilo da je grad disao u istom duhu dočekavši talijansku vojsku kao savezničku i oslobodilačku. No, već nakon nekoliko dana postalo

60 ASMM, busta „Millo“.

61 Conti chiari, amici cari, Narodni list, br. 52, 7. studenog 1918.

62 Italija i Jugoslavija, Narodni list, br. 52, 7. studenog 1918.

63 Kako je Jugoslavenima u Zadru, Narodni list, br. 58, 5. prosinca 1918.

64 ASMM, busta „Millo“. Millo al Comando Supremo del R. Esercito - Udine all’Ufficio del Capo di Stato Maggiore della Marina militare - Roma, (?) prosinac 1918.

65 HR-DAZD-118, Građansko povjerenstvo za Zadar i okupiranu Dalmaciju (1918-1921), kut. 1.

66 Premetačine u Čitaonici, Sokolu i Akademskom klubu, Hrvatska Kruna, br. 46, 4. prosinca 1918.

67 Odbor Narodnog vijeća pisao je Clemenceau „u ime jugoslavenskog stanovništva grada Zadra koje broj 7000 duša od ukupnih 14000, kao i u ime ukupnih 30000 jugoslavenskog stanovništva zadarske obćine koja ukupno ima 37000 duša“. Predsjedniku Clemenceau brzojavno su se obratila i sva sela zadarske općine „uzdajuć se u okušano pokroviteljstvo plemenitog francuzkog naroda da će se svim silama zauzeti da i jugoslavenska obćina Zadar po načelu samoodređenja naroda, bude sjedinjena sa majkom zemljom Jugoslavijom“. Proti tudjincu, Narodni list, br. 58, 5. prosinca 1918. 
je jasno da okupacija nije (samo) vojnog karaktera - utemeljena na uvjetima Ugovora o primirju s Austro-Ugarskom - već, prije svega, i političkog karaktera. Takve spoznaje aktivirale su hrvatske političke snage i nanovo formirale podijeljene nacionale tabore u gradu.

\section{ZADARSKI HRVATI I TALIJANI TIJEKOM POSLIJERATNIH MIROVNIH KONFERENCIJA (1919. I 1920.)}

Početak mirovne konferencije u Parizu, u siječnju 1919., unio je dodatne napetosti u zadarske međunacionalne odnose. Talijani su očekivali potpunu ili barem što veću primjenu odredbi Londonskog ugovora, a "Jugoslaveni“" su očekivali primjenu principa narodnosti pri raspodjeli bivših austro-ugarskih zemalja. Obje strane uložile su sve sile da na različite načine utječu na pregovaračke skupine. Načelnik Ziliotto na sjednici zadarskog gradskog vijeća na dan početka konferencije (18. siječnja 1919.) govorio je o pravu Italije na Dalmaciju te je brzojav takvog sadržaja adresirao na pregovarače u Parizu. ${ }^{69}$ I dalmatinski su Hrvati, uz službeno izaslanstvo Kraljevine SHS, pripremali različite akcije lobiranja u Parizu. Tako je primjerice predsjednik Pokrajinske vlade za Dalmaciju Ivan Krstelj pozvao zadarskog nadbiskupa i dalmatinskog metropolita Vinka Pulišića da se pridruži izaslanstvu svećenstva koje je „povelo akciju, da jedna deputacija biskupa i sveštenika podje u Pariz te da na ime pučanstva Dalmacije i evangjevske pravednosti zatraži od Predsjednika Wilsona te od drugih državnika Entente, da Dalmacija bude pripojena Jugoslaviji“ “70 Diplomatske aktivnosti istovremeno su podupirane različitim metodama i na ulicama Zadra: grad je oblijepljen plakatima s parolama poput „Živila velika Italija!“, „Živila talijanska Dalmacija!“, „Živili Sonnino i Orlando!“, „Živio D.r. Ghiglianovich!“, „Dolje Bissolati!“, „Dolje Milcovich!“.71 Netrpeljivost su širili

69 Natale KREKICH, L'opera amministrativa e politica di Luigi Ziliotto, La Rivista Dalmatica, sv. 1-2, Zadar, 1932., 96; I documenti diplomatici Italiani, Ministero degli affari esteri, Commissione per la pubblicazione dei documenti diplomatici (dalje skraćenicom: DDI), Sesta serie: 1918-1919, Volume II (18 gennaio - 23 marzo 1919), Roma, 1980., 14.

70 HR-AZDN-40, Osobni fond Vinko Pulišić, kut. 17. U duhu svojih stavova nebavljenja političkim pitanjima, Pulišić je odbio poziv, ali je za to ovlastio splitskog biskupa Jurja Carića. (Na istom dokumentu, Krsteljevu dopisu, na poleđini je Pulišić vlastoručno napisao „ovlašten Carić“).

71 Gradske viesti, Hrvatska Kruna, br. 3, 18. siječnja 1919.; Novo Doba, br. 13, 17. siječnja 1919. Parole protiv Leonide Bissolatija, socijalista u Orlandovoj vladi, upućivane su zbog njegovih rezervi oko primjene Londonskog ugovora. Nije pak jasno zašto su izrazi protivljenja išli na račun Ludovica Milcovicha, izrazitog zadarskog iredentista i političkog radikala koji je s Italom Boxichem 1908. osnovao Partito Italiano Democratico te je tijekom rata prebjegao u Italiju. 
i mnogi pojedinci iz javnog života Italije (političari, novinari, publicisti, vojne osobe...) obilazeći okupirana područja - osobito Zadar - i vršeći propagandu za primjenu Londonskog ugovora na mirovnoj konferenciji. Jedan od drastičnijih primjera izljeva mržnje prema dalmatinskim Slavenima svakako je govor izvjesnog poručnika Enza Ferrarija koji je u kazalištu Verdi izjavio da se „ne može (se) dozvoliti da skupine talijanske budu podušene od slavenskog valovlja, da Talijani u Dalmaciji budu progutani od jednog naroda, koji je po kulturi i civilizaciji inferioran, od naroda, koji nije znao dati drugo Austriji, nego policajca, uhoda i krvnika“" ${ }^{72}$ Takav diskurs poticao je pojedine Talijane - ponajprije mlađu populaciju - na iskaze neprijateljstva prema slavenskim sugrađanima: od primjerice rušenja zastave na sokolskoj zgradi ${ }^{73}$ do ozbiljnog međunacionalnog incidenta prilikom dolaska nekakve delegacije iz Firenze kada je u kazalištu Verdi priređena manifestacija predaje zastave („cerimonia della consegna di una bandiera“). Po završetku ceremonije, dok su sudionici prolazili ispred Bogoslovije, dvojica bogoslova navodno su ih vrijedala gestikulirajući i dobacujući pogrdne povike. Talijani su potom uzvratili porazbijavši prozorska stakla na Bogosloviji i Hrvatskoj čitaonici. Ovaj događaj poprimio je tolike razmjere da su u njega bile uključene kako crkvene vlasti u Vatikanu tako i najviše civilne vlasti u Rimu. ${ }^{74} \mathrm{Na}$ lokalnoj razini ovim slučajem bavila se zadarska općina koja je upravi Bogoslovije uputila protestnu notu, ${ }^{75}$ te hrvatske novine koje su, poput Narodnog lista, stale u obranu bogoslova prebacujući krivnju na povorku koja je „navalila na bogoslovno sjemenište (...) psujuć i grdeć nas i naše svetinje“ ${ }^{76}$

Uhićenja i internacije politički aktivnih pojedinaca, koje su vojne vlasti jačim intenzitetom počele provoditi u ožujku 1919., djelovale su na ionako nestabilne

72 Gradske viesti, Hrvatska Kruna, br. 6, 8. veljače 1919. Na ovu izjavu požalili su se vojnim vlastima u gradu predsjednik Dalmatinskog sabora Vicko Ivčević, povjerenik Zemaljske vlade za Dalmaciju u Splitu za Zadar Jerko Machiedo i Ivo Prodan. Uz izraze žaljenja obećano im je da će se izvješćivanje o ovakvim nastupima ubuduće spriječiti cenzurom.

73 Kulturno djelo, Branik, br. 60, 20. veljače 1919.

74 HR-AZDN-16/1, Presidijalni i povjerljivi spisi zadarskih nadbiskupa. Urudžbeni zapisnik, br. 372 (1919.). O incidentu je zamjenika Državnog tajnika Svete Stolice Federica Tedeschinija obavijestio nadbiskup Pulišić, 27. ožujka 1919. Tedeschini odgovara Pulišiću na njegov dopis od 7. ožujka 1919. u kojem ga Pulišić obavještava o „nekim neredim u bogoslovnom sjemeništu“. U svom odgovoru Tedeschini navodi da je naloženo Kongregaciji sjemeništâ „da piše dalmatinskim biskupima da se marnije zauzmu za starješine bogoslovnog sjemeništa“. DDI, Sesta serie: 1918-1919, Volume II, 541. General Scipioni o ovom je slučaju brzojavno obavijestio ministra Sonnina proslijedivši mu Millov brzojav.

75 HR-AZDN-5, Centralno bogoslovno sjemenište, sv. 1919., br. 16, 8. ožujka 1919.

76 Neredi, Narodni list, br. 10, 7. ožujka 1919. 
međunacionalne odnose. Internacije istaknutih osoba iz javnog života kod Hrvata su uzrokovale malodušnost, dok su Talijanima posebnu neugodu i bojazan izazvale za njih nepovoljne vijesti s mirovne konferencije o Wilsonovu odbijanju Londonskog ugovora kao akta koji bi bio polazište u radu konferencije, ${ }^{77}$ a zbog čega se talijanska delegacija demonstrativno privremeno povukla s pregovora. Sukobi su se dogodili početkom svibnja kada su gradske vlasti obilježile šest mjeseci od ulaska talijanskih mornara u grad. Prolazeći gradskim ulicama, masa je uzvikivala „Abbasso i Croati “" ${ }^{78}$ a u ulici između Grand Hotela i Caffè Providenza osvanuli su uvredljivi rogovi s natpisom „M.... S.H.S“. ${ }^{79}$ Napetu atmosferu poticali su politički vođe dalmatinskih Talijana organizacijom različitih manifestacija i demonstracija. Obeshrabren stanjem na mirovnoj konferenciji, Ziliotto je u kazalištu Verdi tada grmio kako će "Zadar znati usvojiti načelo „Italija ili smrt“ te da će prije negoli ostave grad „neprijatelju“, sve kuće i svo blago biti zapaljeni, da neprijateljeva stopa ne stane na njih “ ${ }^{80}$ Splitske novine Novo Doba izvještavale su, možda i s određenom dozom pretjerivanja, o „teroru u Zadru“: napadima na „naše“, tučama, ranjavanjima više desetaka osoba, provaljivanjima u stanove uglednih hrvatskih obitelji i slično. ${ }^{81}$ Talijanski La Voce Dalmatica bez uvijanja je vodeće jugoslavenske političare Trumbića i Korošeca nazivao „praščadi“ i o drugima govorio kao "paščadi“ ${ }^{82}$ što je zasigurno izravno pridonosilo stvaranju netrpeljive međunacionalne atmosfere $u$ Zadru.

Na slabljenje morala zadarskih Talijana i ujedno na jačanje njihove netrpeljivosti prema slavenskim sugrađanima osobito je utjecao stav nove talijanske vlade oformljene koncem lipnja 1919. s Francescom Nittijem na čelu. Lijevo i liberalno orijentirani premijer nastojao je što prije riješiti jadransko pitanje, razriješiti granična pitanja s Jugoslavijom te time stabilizirati unutarnju situaciju u Italiji i izbjeći sukob s velikim silama saveznicama, bez obzira na teritorijalne ustupke $u$ odnosu na Londonski ugovor. Nitti nije podržavao ni Millovu iredentističku politiku u okupiranoj Dalmaciji, čime je kod dalmatinskih Talijana izazivao bijes i ogorčenje. Teška ekonomska

77 Ferdo ŠIšić, Jadransko pitanje na konferenciji mira u Parizu. Zbirka akata i dokumenata, Zagreb, 1920., 30 - 32.

78 Proslava semestra okupacije, Hrvatska Kruna, br. 16, 8. svibnja 1919.

79 Neki zadarski talijanaši, Hrvatska Kruna, br. 16, 8. svibnja 1919. U članku se dodaje da je „taj čin, zgadio (je) okupacijonu vlast, te je ista naredila da se uvrjedljivi znakovi skinu, što su na svoju veliku žalost odmah učinili““.

80 Manifestacije u Zadru: Načelnik dr. Ziliotto prijeti paležom, Novo Doba, br. 99, 8. svibnja 1919.

81 Teror u Zadru, Novo Doba, br. 109, 20. svibnja 1919.

82 Gradske viesti, Hrvatska Kruna, br. 17, 28. svibnja 1919. 
situacija dodatno je opteretila odnose Talijana u Dalmaciji i vlade u Rimu. ${ }^{83}$ Suprotstavljeni stavovi Rima i Dalmacije zaoštrili su se posebice u rujnu 1919. kada je D’Annunzio ušao u Rijeku. Tom prilikom u Zadru su u čast D’Annunzija o ponoći slavila katedralna zvona što je privuklo na ulice nemali broj građana, a jutro je osvanulo sa zacrnjenim natpisima na hrvatskim trgovinama, bankama, odvjetničkim uredima te crnim križevima na vratima stanova nekih hrvatskih obitelji. ${ }^{84}$ Frenetični izljevi nacionalističkih osjećaja uslijedili su za D’Annunzijeva posjeta Zadru 14. i 15. studenog iste, 1919. godine. Njegovi govori, kao i oni njegovih domaćina - Milla i Ziliotta, poticali su na netrpeljivost prema zadarskim Slavenima. Skupine manifestanata marširale su gradom uzvikivajući parole „Abbasso Croazia“ i „Fora i schiavi“ te pjevajući pjesme poput „Colle teste dei Croati - zogheremo le borelle“ ili „La bandiera Jugoslava - Sempre è stata la più sporca - La vogliamo sulla forca“. Širile su se glasine da će zadarski Slaveni biti ukrcani na brodove te da će tako na silu morati napustiti grad; da će biti raspušteni Zemaljski odbor i Prizivni sud, a njihovi službenici deportirani. ${ }^{85}$ Najozbiljniji incident tijekom D’Annunzijeva dvodnevnog posjeta Zadru bio je nasilan upad ardita i nekih zadarskih Talijana u nadbiskupsku palaču i bogoslovno sjemenište. Budući da ove crkvene ustanove nisu poput većine javnih ustanova u gradu izvjesile sagove i talijanske zastave u čast pjesnikova dolaska, jedna grupa od nekoliko zadarskih D'annunzijevih dobrovoljaca (među kojima su bili neki Storich, sudbeni savjetnik, i Calebich, financijski činovnik) preko balkona je ušla u kuriju gdje su izvjesili talijansku zastavu. Nadbiskup Pulišić izjavio im je da se ne bavi politikom te da mu nije poznato da je D’Annunzio u Zadru. Svjetina okupljena pred kurijom uzvikivala je pogrdne riječi na njegov račun nazivajući ga da je „lažac“ i "popovska svinja“. ${ }^{86}$ Također, zbog neisticanja talijanske zastave i svečanih sagova na prozorima brutalno je napadnut i ravnatelj Centralnog bogoslovnog sjemeništa Nikola Tabulov Truta. Nekoliko vojnika u pratnji jednog mladića i dvojice dječaka iz grada upali su u bogosloviju tražeći od njega da izvjesi zastavu. Truta se pravdao da nema zastave te da zavod ne sudjeluje u političkim aktivnostima. Na to mu je jedan od vojnika zaprijetio pištoljem, a „(...) drugi jedan vojnik, po govoru Zadranin, stane vikati i psovati

83 O tome vidi više: Dragan R. Žıvojınović, Političko-ekonomske prilike u Zadru 1919. godine, Zadarska revija, sv. 6, Zadar, 1969.

84 Viesti iz Grada i okolice, Narodni list, br. 30, 26. rujna 1919.; Gradske viesti, Hrvatska Kruna, br. 26, 4. listopada 1919.

85 HR-DAZD-430, Osobni fond Ante Kitarević, kut. 11. Ante KIsIĆ, „Malo zadarske kronike“, 1 - 11.

86 HR-DAZD-430, Osobni fond Ante Kitarević, kut. 11. Ante KIsıć, „Malo zadarske kronike“, 5 - 6. 
da je sramota što se ne sudjeluje u veselju grada, koji je talijanski i u Italiji, nek stranci odlaze: tko hoće da govori hrvatski nek ide na Velebit itd. ${ }^{\text {(87 }}$

Razvidno je da su okupacijske vlasti ako ne poticale, onda sasvim benevolentno tolerirale i nekažnjavale različite oblike iskaza netrpeljivosti Talijana prema Hrvatima. Govoreći o takvim događajima prilikom D’Annunzijeva dolaska u Zadar, splitsko Novo Doba dobro je prozrelo da „(...) moralno auktorstvo za mnoge zločine nose domaći izrodi i njihovi vodje, ali da ne znadu da će im okupatorna vlast svemu doći u susret, ne bi se toliko usudjivali“" ${ }^{88}$ Kako su pregovori Italije i Kraljevine SHS o uređenju granica bili u fazi u kojoj se kraj nije nazirao - a pritom je bilo jasno da je talijanska strana u permanentnoj defenzivi i na nepovratnim pozicijama u odnosu na odredbe Londonskog ugovora - tako je i slabio nacionalni naboj među talijanskim stanovništvom grada. Frenetična raspoloženja iz studenoga i prosinca 1918. u vrijeme dolaska prvih torpiljarki postepeno su kopnjela, a politički prvaci teško su is vremena na vrijeme euforičnim političkim mitinzima uspijevali pridobiti simpatije zadarskih Talijana. Tijekom 1920. godine, do postizanja talijanskojugoslavenskog dogovora oko granica u Rapallu u studenome, zadarska je svakodnevica bila znatno drugačija od prvih dana okupacije. Besparica, a nerijetko i bijeda uzrokovana tek završenim ratom i neizdašnim financijskim potporama talijanske vlade Zadranima je odvraćala fokus interesa od političkih pitanja. Gradski političari i kreatori iredentističke politike na čelu sa Ziliottom, uz pritajenu Millovu potporu, pozivaju na otpor prema politici vlade u Rimu koja je uz velike ustupke kanila što prije završiti pregovore s Jugoslavenima. Prijete paležom i miniranjem grada te krvavim borbama ako Zadar pripadne Jugoslaviji. ${ }^{89}$ Tek rijetki zadarski Talijani početkom 1920. nasjedaju na takve izazivačke govore. Zabilježeni su manji incidenti poput gađanja kamenjem zgrade Sokola, što je činila „zadarska dječurlija“,90 ili zviždanja Anti Tresiću i povika protiv Jugoslavije prilikom prolaska parobrodom. ${ }^{91}$ Pred kraj 1919. godine pokrenuti Naš list hrvatsko-srpske provenijencije u veljači 1920 . proziva za teroriziranje „nekoliko zviždača i tobožnjih vođa, koji su svojim bezumnim i nepolitičkim vladanjem kompromitirali sadašnjost i budućnost

87 HR-AZDN-16/2, Opći spisi Zadarske nadbiskupije, 1919., br. 1866. 15. studenog 1919. Izvješće Nikole Tabulov Trute Nadbiskupskom ordinarijatu.

88 Pismo iz Zadra, Novo Doba, br. 192, 10. prosinca 1919.

89 Vidi npr. članak Nesnosno stanje u Zadru, Novo Doba, br. 18, 24. siječnja 1920.

90 Iz grada i okolice, Naš list, br. 26, 17. ožujka 1920.

91 Tresićev doživljaj u Zadru, Novo Doba, br. 46, 25. veljače 1920. 
Zadra“.92 Čak se ekskulpiraju okupacijske vlasti za neke poduzete mjere jer „da se kroz sve znatnije i neznatnije događaje okupacije redovito i posvuda vuče crvena nit opakosti, mržnje, osveta, intriga sa strane ono nekoliko ljudi, koji se smatraju predstavnicima talijanstva u Dalmaciji (...) i kad bi se iz tog tkiva okupacije mogla iščupati ona nit, slika bi sasvim drukčije izgledala". ${ }^{93}$ Ipak, Millova je vlada provodila različite oblike političke represije bez obzira na veći ili manji upliv domaćih Talijana. Tako je u lipnju 1920. raspušten Jugoslavenski Sokol, vršene su premetačine u crkvi sv. Mihovila, u raznim hrvatskim i srpskim društvima i na Sudu, ${ }^{94}$ a sljedećeg mjeseca rulja je demolirala redakciju i štampariju Narodnog lista ${ }^{95}$ nakon što je sredinom lipnja policija upala u tiskaru, a guverner Millo obustavio izdavanje na mjesec dana. ${ }^{96}$

Privođenje završetku talijansko-jugoslavenskih mirovnih pregovora $u$ jesen 1920. donijelo je zadarskim Talijanima nova ogorčenja. Svjesni činjenice da su predjeli Dalmacije obećani Italiji Londonskim ugovorom nepovratno izgubljeni, a da je otvoreno i pitanje suvereniteta na Zadrom, politički prvaci dalmatinskih Talijana našli su se u nezavidnom položaju - prema sunarodnjacima u Dalmaciji trebali su zastupati isključivu politiku talijanstva Dalmacije, dok su prema vladi u Rimu trebali voditi realnu politiku računajući pritom i na vlastite interese. ${ }^{97}$$$
\begin{aligned}
& \text { Doba, br. } 1 \\
& \text { lipnja } 1920 .
\end{aligned}
$$

95 Vandalizam u Zadru, Novo Doba, br. 159, 19. srpnja 1920.

96 „Narodni list“ obustavljen, Naš list, br. 49, 16. lipnja 1920. Nakon toga Narodni list nije više izlazio.

97 Politički vođe dalmatinskih Talijana istovremeno su razgovarali s visokim predstavnicima talijanske vlade nudeći pritom sasvim drugačija rješenja od onih s kojima su nastupali pred „zadarskom ulicom“. Tako je primjerice Ziliotto pred ugovor u Rapallu uputio ministru vanjskih poslova Carlu Sforzi dva prijedloga za dogovor s Jugoslavenima koji su daleko od pozicija iz Londonskog ugovora te kao takvi predstavljaju usklađenost s temeljnim postavkama pregovaračke politike Italije u tom trenutku. Za podržavanje vladine politike Ziliotto, Ghiglianovich i Salvi imenovani su senatorima već tri dana nakon potpisanog Rapallskog ugovora. Promemorije Diritti degl'Italiani che restano in Jugoslavia i Zara objavljene u: Luigi Ziliotтo (ur. Giuseppe Ziliotto), In difesa di Zara, prima e dopo Rapallo, La Rivista Dalmatica, 4/1982., 270 - 273. Scheda senatore Ziliotto Luigi - Senato della Repubblica, digitalno izdanje, posjećeno 22. prosinca 2016. http://notes9.senato.it/web/senregno. NSF/0894723caa72fabbc12571140059964f/927c93ec3818dab14125646f006197c5?OpenDocume nt; Scheda senatore Ghiglianovich Roberto - Senato della Repubblica, digitalno izdanje, posjećeno 22. prosinca 2016., http://notes9.senato.it/web/senregno.NSF/65a0a8ced8361de0c12571140059a1c 7/808e30be2b451e314125646f005c299b?OpenDocument; Salvijevo imenovanje: Oscar RANDI, Il senatore Roberto Ghiglianovich, mezzo secolo di storia Dalmata, La Rivista Dalmatica, sv.2, Zadar, 1986., 96. Salvijevo imenovanje ne nalazi se na mrežnim stranicama talijanskog Senata i nema ga na popisu senatora (poput Ziliotta i Ghiglianovicha), vjerojatno zato što je četiri dana od imenovanja preminuo te nije ni preuzeo službu i položio zakletvu. 
I tako su postupali. Među njihovim posljednjim većim akcijama koje su imale za cilj uzbunjivanje građana i iskazivanje otpora prema službenoj politici Italije na mirovnim pregovorima bio je zbor predstavnika zadarske općine, bivših zastupnika, članova Fascio nazionale i drugih udruga koji je organiziran u Zadru 13. listopada 1920. Donesena je rezolucija kojom se najoštrije osuđuju postupci talijanske vlade u pogledu teritorijalnih popuštanja u Dalmaciji te se ujedno prijeti otporom uz pomoć „velikodušnih ljudi koji se ponose veličinom Italije“ ako Dalmacija pripadne Jugoslaviji. „Za krv koja će se proliti“ odgovornom smatraju upravo vladu u Rimu.$^{98}$ Rješenje jadranskog pitanja koje je ubrzo potom uslijedilo ugovorom u Rapallu uzrokovalo je kod zadarskih Talijana osjećaje očaja. Ne samo zbog činjenice da je Rapallski ugovor značajno obeskrijepio Londonski pakt, čime je Italija dobila bitno manje teritorija, već i zbog svijesti da će Zadar, kao izolirani otočić u slavenskoj državi, imati ekonomskih poteškoća ako Italija ne bude izdašna u financijskim potporama. Tako su koncem 1920. osjećaji ogorčenosti, ali i otvorenog bijesa, bili usmjereni ne više prema slavenskim sugrađanima, nego prema vladi u Rimu. Uspostavom legalnih civilnih vlasti nakon dvije godine provizorne Millove administracije, u svim segmentima temeljene na vojnoj upravi, nastupilo je mirnodopsko razdoblje i uređenje odnosa sa susjednom Jugoslavijom, ali i sasvim novo razdoblje hrvatsko-talijanskih odnosa u gradu. Talijanska uprava na mnoge je načine poticala nacionalnu asimilaciju netalijanskog stanovništva ne ostavljajući pritom prostora za nacionalna prava i slobode drugim narodnima. Duh takve politike prenio se i među građanstvo: neprihvaćanje svekolikog talijanstva Zadra vodilo je pojedince i obitelji društvenoj izolaciji ili napuštanju grada.

\section{ZAKLJUČAK}

Pod vidikom nacionalne pripadnosti, odnosi zadarskih Hrvata i Talijana tijekom zadnjih desetljeća Habsburške Monarhije i talijanske okupacije od kraja Prvog svjetskog rata do Rapallskog ugovora bili su obilježeni dubokim podjelama. One su se ponajviše manifestirale u različitim idejno-političkim konceptima konstitucionalnog uređenja Dalmacije formiranim tijekom nacionalnih integracija druge polovice 19. stoljeća: na autonomističkom i aneksionističkom konceptu s kojima su se identificirale pojedine skupine. Valja međutim istaknuti

98 Naši se talijanaši spremaju na otpor, Novo Doba, br. 236, 19. listopada 1920. Pomoć „velikodušnih ljudi“ odnosi se zasigurno na D’Annunzija i njegove ardite.; L. MonZALI, Italiani di Dalmazia, Dal Risorgimento alla Grande Guerra, 199, 200. 
činjenicu da ta identifikacija nije slijedila isključivo po principu nacionalne pripadnosti, to jest da su svi Talijani prigrlili autonomistički, a svi Hrvati aneksionistički politički pravac. Mnogi primjeri iz dalmatinskog društvenopolitičkog života tog vremena potkrepljuju navedenu tvrdnju kako na jednoj tako i na drugoj strani.

Međunacionalne podjele u Zadru mogu se pratiti barem na tri razine: na razini političkih elita, na razini novina kao izvještajnih organa pojedinih političkih stranaka, ali i među svakodnevnim međuljudskim odnosima što su suvremenici često opisivali pojmom ulica. Na ulici je često dolazilo do verbalnih, ali i fizičkih obračuna pojedinaca i grupa koji su nerijetko bili instrumentalizirani od svojih političkih vođa.

Objavom rata Italije Austro-Ugarskoj zadarski su Talijani postali potencijalni neprijatelji države koja je budno pratila djelovanje njihovih istaknutih društvenopolitičkih pojedinaca. Međutim, na razini odnosa s hrvatskim sugrađanima tijekom rata nije bilo ozbiljnijih narušavanja međusobnih odnosa na nacionalnoj razini. Svršetak rata i iznenadni dolazak talijanske vojske načas je ujedinio nacionalne elemente u Zadru: Hrvati (i Srbi) priključili su se talijanskim sugrađanima u slavlju zbog propasti stare Monarhije i u iskazivanju dobrodošlice talijanskoj vojsci kao sili saveznici, vjerujući da je okupacija privremenog karaktera, u cilju osiguranja javne sigurnosti i aprovizacije. Međutim, talijanska je politika okupacijom zapravo željela ako ne prejudicirati onda barem usmjeriti ishod mirovnih pregovora tako da su okupacijske vlasti pomalo stavile pod kontrolu gotovo sve segmente javne uprave. To je proizvelo otpor netalijanskog stanovništva i ujedno potaklo međunacionalne netrpeljivosti i sukobe.

Dugotrajni mirovni pregovori tijekom kojih je Italija pomalo gubila pozicije savezničkih obećanja iz Londonskog ugovora uzrokovali su dodatne netrpeljivosti među zadarskim Hrvatima i Talijanima. Represije Millove okupacijske vlade i njegovo koketiranje s D’Annunzijem negativno se odražavalo na nacionalne odnose u gradu. Zadarski načelnik Luigi Ziliotto i drugi istaknuti talijanski političari svojom su isključivom politikom („Italia o morte!“), ne obazirući se na princip narodnosti, činili tešku štetu i Hrvatima i Talijanima Zadra. Ne samo da je (i) zbog njihova žestokog lobiranja u Rapallu dogovoreno za Zadar možda najgore rješenje, već su svojom huškačkom politikom poticali neprijateljstva i netrpeljivost prema netalijanskom stanovništvu grada. Stoga su u razdoblju provizorne uprave vlade Enrica Milla, zahvaljujući prije svega domaćim talijanskim političarima, međunacionalni odnosi u Zadru bili opterećeni mnogim osobnim i kolektivnim netrpeljivostima. $U$ takvoj atmosferi nadolazeći fašizam predstavljao je tek formu i nadogradnju. 
Ante GVERIĆ

CROATIAN-ITALIAN RELATIONS IN ZADAR AT THE TIME OF THE COLLAPSE OF AUSTRO-HUNGARIAN MONARCHY AND ITALIAN OCCUPATION (1918-1920)

\section{SUMMARY}

Starting from the hypothesis arguing the Italian character of Zadar as the sole municipality in Dalmatia that had during the process of national integrations stayed under the authority of Italian Party, the paper primarily analyses the national structure in Zadar during the final couple of decades of Austrian management in Dalmatia. The relations between the Zadar Croats and Italians had to survive grave phases of intolerance and mutual conflicts in these final years of Austrian management. During the war between Italy and Austro-Hungarian Monarchy, no serious conflicts occurred, primarily thanks to the extreme repression by the state towards all the subversives. At the end of the war and after the capitulation of Austro-Hungary, all national groups in Zadar were only for a brief time united in celebrating the collapse of the Black-Yellow Monarchy. The unity continued even during entering port of warships, by which Italian soldiers, on behalf of the Entente, occupied former Austrian lands with the aim of preserving public order and implementing rationing. However, the policy conducted by Italian government aimed at occupying as large a part of Dalmatia as possible, securing a better position in the coming peace negotiations, and thus directing their outcome. Occupational military authorities and local Italian politicians were openly conducting such a policy, causing thereby resistance of the non-Italian population; this led to many regime-orchestrated repression measures. Intolerance and conflicts were conveyed to the public, and hence became a part of the everyday life in Zadar during the occupation. Since in peace negotiations, the official Italian state policy was gradually withdrawing of the pretentious territorial demands based on the London Agreement, Dalmatian Italians felt betrayed by the government in Rome. In 1920, under the pressure of the increasingly difficult economic situation and the unfavourable news arriving from piece negotiations, they ceased falling for inflammatory speeches held by local political leaders.

The relations between the Zadar Croats and Italians are in this paper analysed divided in three periods and at three different levels: during the final decades of Austro-Hungarian Monarchy; at the time of the collapse of the Monarchy in 1918; and during the after-war piece conferences (in 1919 and 1920). As concerns 
different levels of their relations, the following ones may be recognised: the level of political elites; newspapers as the heralds of political parties; and the level of the street - term that contemporaries often used in order to describe not only the venue, but - figuratively - also the nature of international conflicts that was conveyed from high political spheres to the public.

Keywords: Croats; Italians; conflicts; Zadar; Austro-Hungarian Monarchy; 1918; Italian occupation. 